\title{
Response of Seed Size and Plant Density on Growth, Yield and Grain Quality of Bread Wheat (Triticum aestivum L.) Varieties Under Vertic Luvisols of Kulumsa in Arsi Zone
}

\author{
Author: Anbessie Debebe Aboye \\ Ethiopian Institute of Agricultural Research, Kulumsa Agricultural Research Center, Inorganic Soil Fertility \\ Management Research Program, P. O. Box 489, Asella, Ethiopia \\ Co-author: Dawit Habte Haile \\ Ethiopian Institute of Agricultural Research, Kulumsa Agricultural Research Center, Acid Soil Management \\ Research Program, P. O. Box 489, Asella, Ethiopia
}

This study was self-sponsored project and does not financially sported by any funding organizations

\begin{abstract}
With November the objectives of to determine the optimum plant density levels of bread wheat by identifying the most cost-effective variety, a field experiment was conducted at Kulumsa Agricultural Research Center from June to 2018 cropping season, Three bread wheat varieties (Hidassie, Dendea and Shorima) representing different seed sizes of large, medium, small, respectively and four plant density levels of 250, 300, 350 and 400 plants m $^{-2}$ were tested. The main effect of the varieties seed size on days to $50 \%$ of heading, days to $90 \%$ of maturity, thousand kernel weight and hecto liter weight showed significant $(\mathrm{p}<0.01)$ variations, while number of tillers and spike length indicated statistically significant $(\mathrm{p}<0.05)$ variations. The use of 300 plants $\mathrm{m}^{-2}$ plant density for the variety Hidassie /large seed size/ resulted in highest seedling number (26.30), of tillers (7.50), days to 50\% of heading (63.00), days to $50 \%$ of maturity, (116.00), spike length, $(7.50 \mathrm{~cm})$, thousand kernel weight $(48.22$ gm.), hecto liter weight $(78.30 \mathrm{~kg} / \mathrm{hL})$. The main effect of plant population on number of seedlings and harvest index showed significant $(\mathrm{p}<0.01)$ variations. Number of seedlings and harvest index resulted in (25.31) and (44.05) respectively. The interaction effects of variety and plant density on harvest index, indicated significant $(\mathrm{p}<0.001)$ variation, while grain yield showed statistically significant $(\mathrm{p}<0.01)$ variation, likewise biomass yield and straw yield indicated significant $(\mathrm{p}<0.05)$ variations. The harvest index, resulted in $(43.63 \%)$, while grain yield is (4.309 Ton $\left.\mathrm{ha}^{-1}\right)$, similarly biomass yield and straw yield are (11.00 Ton ha $\left.{ }^{-1}\right)$ and $\left(5.28 \mathrm{Ton} \mathrm{ha}^{-1}\right)$ respectively, and it suggests that these traits are generally enhanced by the genetic makeups of the variety Hidassie /large seed size/. Economic analysis using partial budget procedure was performed on grain yields to determine the treatment with most profitable returns. The beneficial marginal rate of return (8.50) and benefit cost ratio (8.07) was obtained from the variety Hidassie /large seed size/ at a plant density of 300 seeds $\mathrm{m}^{-2}$ followed by a marginal rate of return (9.55) and benefit cost ratio (8.05) were also recorded again from the variety Hidassie /large seed size/ at plant density of 250 plants $\mathrm{m}^{-2}$. So the most cost-effective variety and plant density level for farmers with low cost of production and higher benefits were identified to be the variety Hidassie /large seed size/ at the plant density level of 300 plants $\mathrm{m}^{-2}$ in the rain fed cropping season is identified as low cost of production with highest benefit and can be recommended for the producers of wheat crop. The plant density level of 250 plants $\mathrm{m}^{-2}$ for variety Hidassie /large seed size/ was also cost-effective with highest net-benefit and can be recommended as another possible choice. But, as this study was conducted at one experimental site, it is required to repeat the experiment across locations, soil type, and over-seasons to make agronomically consistent recommendations and economically feasible levels of plant density for bread wheat.
\end{abstract}

Keywords: Bread Wheat Yield, Economic Benefit, Plant Density, Grain Quality, Varieties Seed Size.

DOI: $10.7176 / \mathrm{JNSR} / 11-15-01$

Publication date:August $31^{\text {st }} 2020$

\section{INTRODUCTION}

Bread wheat (Triticum aestivum L.) is the most indispensable cereal crop in the world (Akbar, 2001; Tunio, 2006), and the main source of major food for the populations of Ethiopia. It is one of the various cereal crops largely grown in the highlands of Ethiopia and it produced largely in the southeast, central and northwest parts of the country. Minor amount is produced in the rest of the south and north regions. Ethiopia is the largest wheat producer in Sub-Saharan Africa and bread wheat is the major cereal crops in the Ethiopian highlands, which range between 6 and $16^{\circ} \mathrm{N}, 35$ and $42^{\circ} \mathrm{E}$ and 1500 to $2800 \mathrm{~m}$. At national level, during 2015/16, cropping season 1,664,564.62 ha, of land was covered by bread wheat and durum wheat and producing 42192572.23 metric tons (MoANR, 2016). Presently at the national level about $1,747,939.31$ ha of land is covered by durum and bread 
wheat and over 4,838,074.09 metric tons yield is produced from this land annually (CSA 2018).

It is obvious that bread wheat is one of the main commodity crops known worldwide with respect to its production and economic value which requires good production and management practices. Bread wheat is used in a variety of products, but its use as flour forbread and baked goods is the most prevalent and without bread wheat baked goods, many of our popular plates would lack the appealability and character that make it preferred. One of the key reasons why bread wheat is best suited for bread making in comparison to other grains is its high gluten content. However, the quality and high yield of bread wheat production is depending on production and management practices on both field and after harvested.

Despite its importance and increased production, bread wheat yield and its quality is affected by various biotic and abiotic stresses, among which low or excess mineral nutrition, irrigation schedule or rainfall are among the major ones (Jaleel, 2007; Cheruth et al., 2008). Cultivated wheat is classified into two major types; the hexaploid bread wheat $(2 \mathrm{n}=6 \mathrm{x}=42$, AABBDD) and the tetraploid durum wheat $(2 \mathrm{n}=4 \mathrm{x}=28$, AABB $)$. The two economically important wheat species grown in Ethiopia are durum wheat (Triticum durum), tetraploid of which is with a total chromosome numbers of $2 n=28$ ) and which has 4 sets of chromosomes each with a unique genome of $\mathrm{n}=7$ chromosomes whereas, bread wheat (Triticum aestivum), hexaploid which is with a total chromosome numbers of $2 n=42$ and which has 6 sets of chromosomes each with a unique genome of $n=7$ chromosomes, (Center for New Crops \& Plant Products, Purdue University. 2003).

Currently, at the global level, bread wheat accounts for $95 \%$ of all the wheat produced. Based on growth habit, wheat is classified into spring wheat and facultative/winter wheat, covering about 65 and 35\% of the total global wheat production area, respectively. The flour of bread wheat is used to make French bread, Arabic bread, Chapati, biscuits, pastry products and for the production of commercial starch and gluten (Braun et al., 2010; Braun and Saulescu, 2002).

Bread wheat crop has a thin root system and needs optimum and regular application of water and nutrients. Cropping season and soil moisture may affect the quality and yield of field crops any plants; low moisture conditions in the soil are conducive to poor yields (Shock et al., 1998), while excessive soil moisture results in wastage of irrigation water, nutrients leaching, and may lead to rots and poor seed quality. The crop yields varied considerably among sites and among production seasons at the same site. These variations were probably due to soil, cropping season, amount and type of nutrients available, planting date, degree of plant density and other differences in cultural practices. So far, many varieties of bread and durum wheat have been developed to satisfy the growing production demands and as a result, about 76 bread wheat and 34 durum wheat varieties have been released (MOANR, 2016).

Despite the large area cultivated for wheat, the national average yield of wheat in Ethiopia is about 2.768 metric tons ha ${ }^{-1}$ (CSA, 2018). This is certainly lower than the world's average yield which is about 3.320 metric tons $\mathrm{ha}^{-1}$ (USDA, 2017). The number of productive tillers is dependent on varieties and environment and strongly influenced by planting density. However, tillering capacity is increased with enough moisture availability, increasing light and optimum nitrogen availability during the vegetative phase and it depends greatly upon varieties (Jamal A. et al., 2015). Seed rate is one of the most important agronomic factors which need great emphasis for maximum yield of crops. High seed rate increases the competition among crops for common resource particularly water, nutrients and sunlight which result in low quality and low yield.

Also, Hameed, et al., (2002) reported that the use of low seed rate leads to low yield due to lesser number of plants per unit area. However, Baloch et al., (2010) reported lower seed rates significantly increased the number of fertile tillers produced per plant which do have pronounced effect on yield of varieties. Beside its yield impact, sowing at a seed rate that result in optimal plant density may also reduce seed costs, lodging \& disease problems which add up extra value in crop production process (N. Majnoun Hosseini, R. H. Ellis and B. Yazdi-Samadi, 2001). A number of bread wheat varieties differing in their seed size, height and maturity as well as tillering capacity have been developed in Ethiopia. However, the recommended seed rate for all the varieties being used across the country is $150 \mathrm{~kg} \mathrm{ha}^{-1}$ (Jamal A. et al., 2015).

Likewise, around the study area there is a trend by farmers to use higher plant density of seed rates for both of small and large sized bread wheat varieties (own observation). According to the research result of A. Zareian, L., et al., (2012), seed size had a significant impact on all of measured traits with the exception of thousand seeds weight. Results indicated that number of seeds per spike significantly decreased by increasing seed size. The other traits showed significant increase by increasing seed size. Varieties seed size had significant effect on thousand seeds weight, but other traits were similar among varieties.

In view of that, it is essential to determine the optimum plant density rates for different seed sized bread wheat varieties in order to improve the production and productivity of the crop by identifying the most cost-effective varieties and profitable plant density rates with low cost of production inputs.

Thus, for this study, three recently released bread wheat varieties namely (Hidassie, Dendea and Shorima) representing standard categorization of seed sizes as small (Shorima), medium (Dendea) and large (Hidassie) with 
plant density rates of $250,300,350$ and 400 plants $\mathrm{m}^{-2}$ were selected and tested to attain the following objectives. Table 1. Bread Wheat Varieties Seed Rate and Plant Density Levels

\begin{tabular}{lllll}
\hline \multicolumn{4}{c}{ Plant Density Levels } \\
\hline Varieties/Seed Size & 250 Plants m$^{-2}$ & $300 \mathrm{Plants} \mathrm{m}^{-2}$ & $350 \mathrm{Plants} \mathrm{m}^{-2}$ & 400 Plants m$^{-2}$ \\
\hline Shorima/Small Sized Seeds & $90 \mathrm{~kg} \mathrm{ha}^{-1}$ & $108 \mathrm{~kg} \mathrm{ha}^{-1}$ & $126 \mathrm{~kg} \mathrm{ha}^{-1}$ & $144 \mathrm{~kg} \mathrm{ha}^{-1}$ \\
Dendea/Medium Sized Seeds & $104 \mathrm{~kg} \mathrm{ha}^{-1}$ & $126 \mathrm{~kg} \mathrm{ha}^{-1}$ & $146 \mathrm{~kg} \mathrm{ha}^{-1}$ & $168 \mathrm{~kg} \mathrm{ha}^{-1}$ \\
Hidassie/Medium Sized Seeds & $118 \mathrm{~kg} \mathrm{ha}^{-1}$ & $142 \mathrm{~kg} \mathrm{ha}^{-1}$ & $166 \mathrm{~kg} \mathrm{ha}^{-1}$ & $190 \mathrm{~kg} \mathrm{ha}^{-1}$ \\
\hline
\end{tabular}

\section{MATERIALS AND METHODS}

\subsection{Description of the Experiment Site}

A field experiment was conducted at Kulumsa Agricultural Research Center (KARC) during the 2018 cropping season. The experiment site is situated at $08^{\circ} 01^{\prime} 10^{\prime \prime} \mathrm{N}$ and $39^{\circ} 09^{\prime} 11 \mathrm{E}$ at an altitude of $2170 \mathrm{~m}$ above sea level at Kulumsa in Arsi Administrative Zone, at $167 \mathrm{~km}$ South East of Addis Ababa. The type of soils in Kulumsa Research Center are known as, Haplic Alisols, Eutric Vertisols and Vertic Luvisols. About 83.07\% of the soil type at Kulumsa Research Center is classified as Vertic Luvisols and about 10.06\% of the soil type is classified as Eutric Vertisols and about $6.87 \%$ of the soil type is also classified as Haplic Alisols (Abayneh et al., 2003). The soils are deep to very deep $(>100 \mathrm{~cm})$ and clayey in texture.

The agro-climatic condition of the area is wet and receives the annual mean rainfall of $809.15 \mathrm{~mm}$ from March to September; however, the peak season is from July to August. The average annual maximum and minimum mean temperatures are 23.08 and $9.9^{\circ} \mathrm{C}$, respectively (Jemal A. et al., 2015). The $\mathrm{pH}$ of the soils ranges from 6.593 to 6.786 and subsurface soils have higher $\mathrm{pH}$ values than surface soils (Abayneh et al., 2003). Kulumsa Research Center is located on very gently undulating topography with a gradient of 0 to $10 \%$ slope. In some places where the slope is very flat, flooding and water logging had still some effects. The soil moisture establishment can be classified as ustic and the soil temperature as Isothermic (Abayneh et al., 2003).

Figure 1. Location of the Study Site in Arsi Zone of Oromiya Region

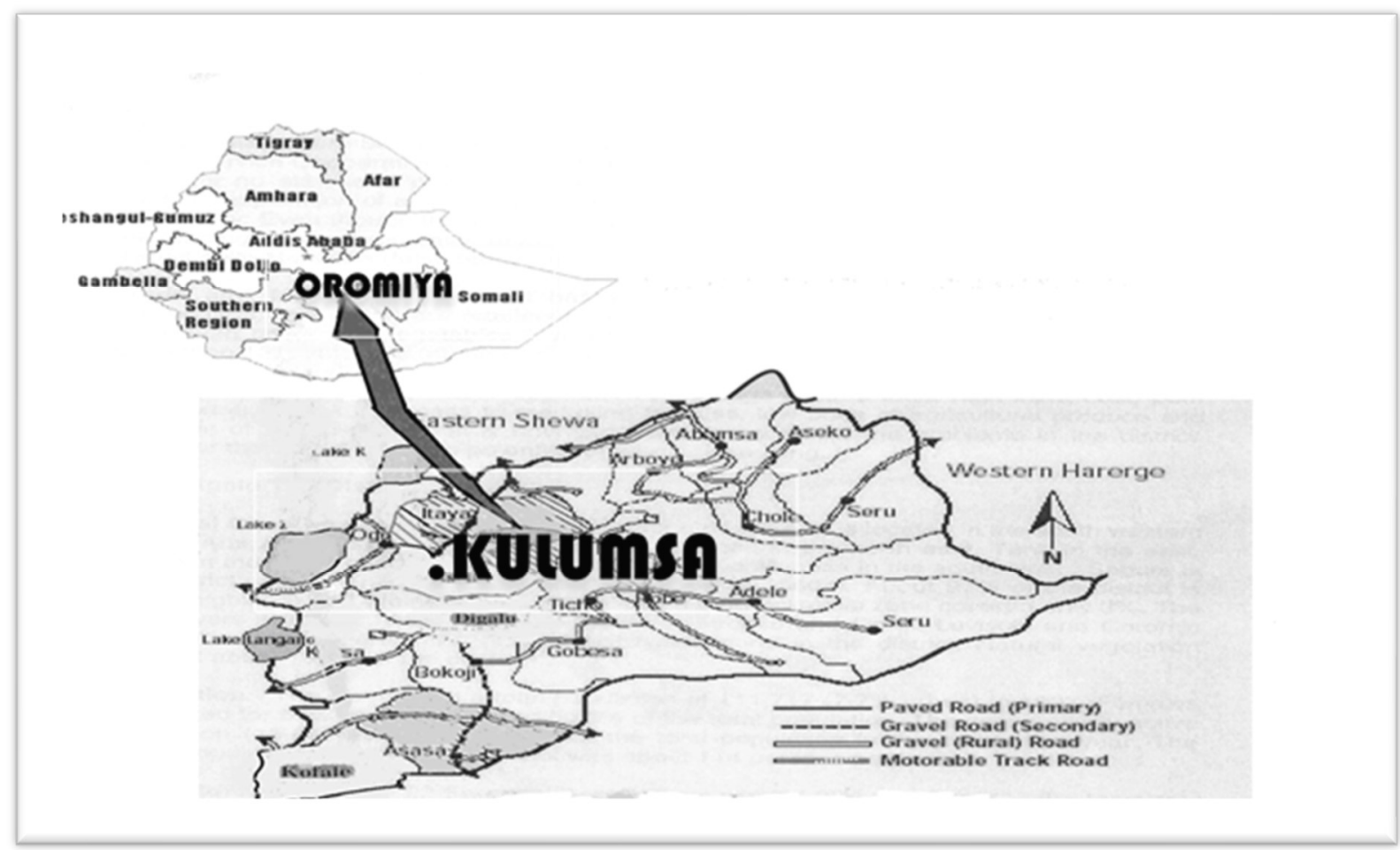

Differences in agro-climatic and vegetation cover with the dissimilarities in parent materials and relief led to the existence of diverse soils in the study area. The soil types of the experiment site are mostly developed from parent materials of volcanic origin, mainly basalt. But, in certain parts, there are soils that were established from alluvial materials. The dominant soil of the area is Luvisols (Abayneh et al., 2003) and bread wheat is the most widely cultivated crop in the area (MoANR, 2016)

The entire growing season rainfalls from June to August was $538 \mathrm{~mm}$ which is above the persistent average in 2018, But under average in October and December, considerably above average during August and September. The crop did not experience serious drought except for a hot dry influence from late October to 
December, which caused initial wilting on several occasions as shown on figure 2.

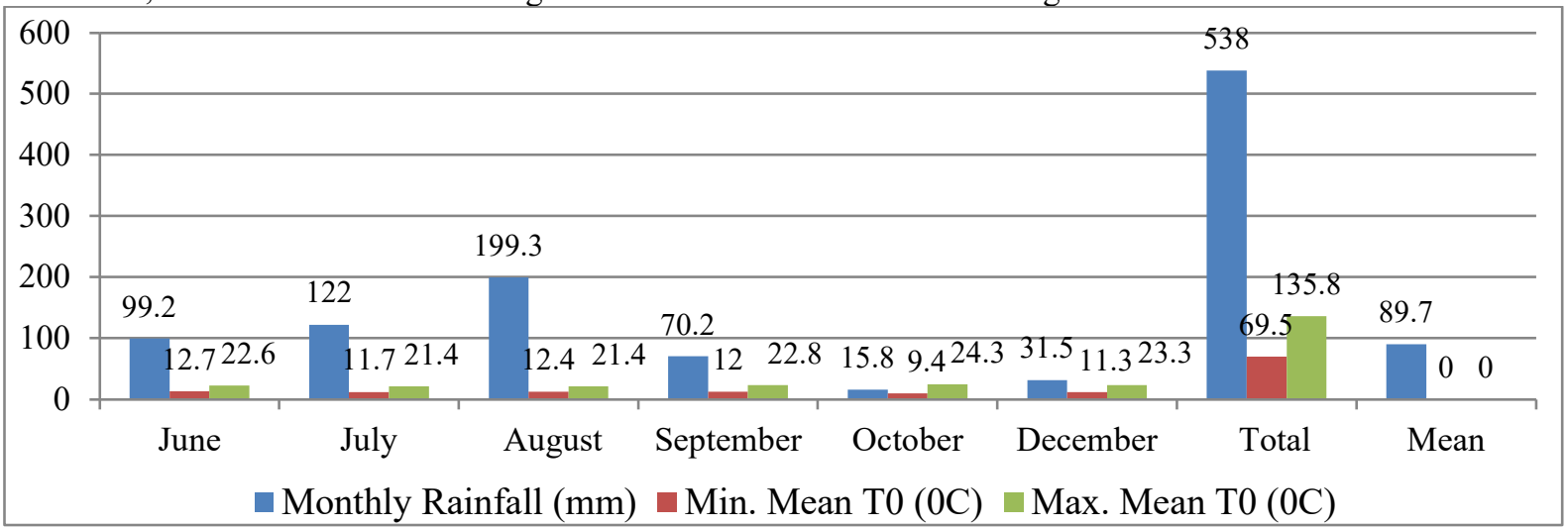

Figure 2. Monthly Total, Mean $\mathrm{T}^{0}$ and Rainfall for the Growing Period of Bread Wheat Crop at Kulumsa

\subsection{Experimental Treatments}

The twelve treatments were used for this experiment and the treatment combination were three varieties of different seed sizes and four levels of plant density. The three bread wheat varieties (Hidassie, Dendea, Shorima) and four plant density levels $\left(250,300,350,400\right.$ plants $\left.\mathrm{m}^{-2}\right)$ were used for the experiment assigned with twelve treatment arrangements. The selected bread wheat varieties were classified in to three broad seed sizes were selected to represent small, medium and large sized seeds of bread wheat. The three varieties with different seed sizes were combined with four plant density levels to make 12 treatment arrangements. These three different sized bread wheat varieties were assigned as main plot treatment, while four different levels of plant density were assigned as sub plot treatments.

Table 2. Treatments Combination Used in the Experiment

\begin{tabular}{|c|c|c|c|c|c|c|c|}
\hline $\begin{array}{c}\text { Treatment } \\
\text { No. }\end{array}$ & Variety & & $\begin{array}{c}\text { Plant } \\
\text { Populations }\end{array}$ & $\begin{array}{c}\text { Treatment } \\
\text { Combination }\end{array}$ & $\begin{array}{l}\text { Seed Rat } \\
\text { Calculati } \\
\text { Method }\end{array}$ & & $\begin{array}{c}\text { Seed } \\
\text { Rate } \\
\left(\mathrm{kg} \mathrm{ha}^{-1}\right)\end{array}$ \\
\hline 1 & $\begin{array}{l}\text { Shorima/Small } \\
\text { Seeds }\end{array}$ & Sized & 250 Plants $\mathrm{m}^{-2}$ & $\mathrm{VS}_{\mathrm{S} 1} \mathrm{PP}_{1}$ & $\begin{array}{l}250 \text { seeds } \mathrm{m}^{-2} \\
\mathrm{mg} / 90 \%=\end{array}$ & $\begin{array}{l}\times 2.590 \\
\end{array}$ & \\
\hline 2 & $\begin{array}{l}\text { Shorima/Small } \\
\text { Seeds }\end{array}$ & Sized & 300 Plants $\mathrm{m}^{-2}$ & $\mathrm{VS}_{\mathrm{S} 1} \mathrm{PP}_{2}$ & $\begin{array}{l}300 \text { seeds } \mathrm{m}^{-2} \\
\mathrm{mg} / 90 \%=\end{array}$ & 32.5108 & \\
\hline 3 & $\begin{array}{l}\text { Shorima/Small } \\
\text { Seeds }\end{array}$ & Sized & 350 Plants $\mathrm{m}^{-2}$ & $\mathrm{VS}_{\mathrm{S} 1} \mathrm{PP}_{3}$ & $\begin{array}{l}350 \text { seeds } \mathrm{m}^{-2} \\
\mathrm{mg} / 90 \%=\end{array}$ & 32.5 & \\
\hline 4 & $\begin{array}{l}\text { Shorima/Small } \\
\text { Seeds }\end{array}$ & Sized & 400 Plants $\mathrm{m}^{-2}$ & $\mathrm{VS}_{\mathrm{S} 1} \mathrm{PP}_{4}$ & $\begin{array}{l}400 \text { seeds } \mathrm{m}^{-2} \\
\mathrm{mg} / 90 \%=\end{array}$ & 32.5 & \\
\hline 5 & $\begin{array}{l}\text { Dendea/Medium } \\
\text { Seeds }\end{array}$ & Sized & 250 Plants $\mathrm{m}^{-2}$ & $\mathrm{VS}_{\mathrm{S} 2} \mathrm{PP}_{1}$ & $\begin{array}{l}250 \text { seeds } \mathrm{m}^{-2} \\
\mathrm{mg} / 90 \%=\end{array}$ & $37.6_{104}$ & \\
\hline 6 & $\begin{array}{l}\text { Dendea/Medium } \\
\text { Seeds }\end{array}$ & Sized & 300 Plants $\mathrm{m}^{-2}$ & $\mathrm{VS}_{\mathrm{S} 2} \mathrm{PP}_{2}$ & $\begin{array}{l}300 \text { seeds } \mathrm{m}^{-2} \\
\mathrm{mg} / 90 \%=\end{array}$ & $37.6_{126}$ & \\
\hline 7 & $\begin{array}{l}\text { Dendea/Medium } \\
\text { Seeds }\end{array}$ & Sized & 350 Plants $\mathrm{m}^{-2}$ & $\mathrm{VS}_{\mathrm{S} 2} \mathrm{PP}_{3}$ & $\begin{array}{l}350 \text { seeds } \mathrm{m}^{-2} \\
\mathrm{mg} / 90 \%=\end{array}$ & 37.6 & \\
\hline 8 & $\begin{array}{l}\text { Dendea/Medium } \\
\text { Seeds }\end{array}$ & Sized & 400 Plants $\mathrm{m}^{-2}$ & $\mathrm{VS}_{\mathrm{S} 2} \mathrm{PP}_{4}$ & $\begin{array}{l}400 \text { seeds } \mathrm{m}^{-2} \\
\mathrm{mg} / 90 \%=\end{array}$ & 37.6 & \\
\hline 9 & $\begin{array}{l}\text { Hidassie/Large } \\
\text { Seeds }\end{array}$ & Sized & 250 Plants $\mathrm{m}^{-2}$ & $\mathrm{VS}_{\mathrm{S} 3} \mathrm{PP}_{1}$ & $\begin{array}{l}250 \text { seeds } \mathrm{m}^{-2} \\
\mathrm{mg} / 90 \%=\end{array}$ & $42.6_{118}$ & \\
\hline 10 & $\begin{array}{l}\text { Hidassie/Large } \\
\text { Seeds }\end{array}$ & Sized & 300 Plants $\mathrm{m}^{-2}$ & $\mathrm{VS}_{\mathrm{S} 3} \mathrm{PP}_{2}$ & $\begin{array}{l}300 \text { seeds } \mathrm{m}^{-2} \\
\mathrm{mg} / 90 \%=\end{array}$ & 42.6 & \\
\hline 11 & $\begin{array}{l}\text { Hidassie/Large } \\
\text { Seeds }\end{array}$ & Sized & 350 Plants $\mathrm{m}^{-2}$ & $\mathrm{VS}_{\mathrm{S} 3} \mathrm{PP}_{3}$ & $\begin{array}{l}350 \text { seeds } \mathrm{m}^{-2} \\
\mathrm{mg} / 90 \%=\end{array}$ & 42.6 & \\
\hline 12 & $\begin{array}{l}\text { Hidassie/Large } \\
\text { Seeds }\end{array}$ & Size d & 400 Plants $\mathrm{m}^{-2}$ & $\mathrm{VS}_{\mathrm{S} 3} \mathrm{PP}_{4}$ & $\begin{array}{l}400 \text { seeds } \mathrm{m}^{-2} \\
\mathrm{mg} / 90 \%=\end{array}$ & $42.6_{190}$ & \\
\hline
\end{tabular}

Note: $V S_{S}=$ variety seed size; $P P=$ plant population; $\mathrm{kg} \mathrm{ha}^{-1}=$ kilogram per hectare

\subsection{Experimental Setup and Procedure}

The field experiment was laid out in a split plot design. The treatments were replicated three times wherein three 
different seed sized varieties were allocated to primary factor and four plant population levels to secondary factor. Land preparation was done by tractor ploughing followed by harrowing. The experiment consisted of 12 treatments with a total number of 36 plots. According to the specification of the design, a field layout was prepared and each treatment was assigned randomly to experimental units within a block. Plot size of each replicated treatments were $2.6 \mathrm{~m} \times 4 \mathrm{~m}$, that consisted of 13 rows. The spacing among plots was $0.5 \mathrm{~m}, 20 \mathrm{~cm}$ between rows, and $1.0 \mathrm{~m}$ amongst blocks respectively. The outer four rows were reserved for border effect and the inner nine rows were for sampling and harvest area of biomass and grain yield.

\subsection{Seed Rates of the Plant Density Levels}

If a variety has a seed weight of $32.5 \mathrm{mg}$ (TKW of $32.5 \mathrm{~g}$ ), and likely establishment (germination $\%$ ) of $90 \%$, the seed rate ha ${ }^{-1}$ for a density of $250,300,350,400$ plants $\mathrm{m}^{-2}$ are calculated by using the following formula for the calculation of seed rates per hectare (Dawit Habte, 2017).

$$
\text { Seed rate }\left(\frac{\mathrm{kg}}{\mathrm{ha}}\right)=\frac{\text { target plants }\left(\frac{\#}{\mathrm{~m} 2}\right) * \text { TKW or seed weight }(\mathrm{mg})}{\text { likely establishment }(\%)}
$$

For instance: Seed Rate $\left(\mathrm{kg} \mathrm{ha}^{-1}\right)=\left(250\right.$ plants $\left.\mathrm{m}^{-2} \times 32.5 \mathrm{mg} / 90 \%\right)=90 \mathrm{~kg} \mathrm{ha}^{-1}$. Alike calculations for similar varieties with comparable thousand kernel weight and seedling germination percent (likely establishment of $90 \%$ ) was calculated for each variety using by the assigned amount of plant density. The seed rates are calculated with likely establishment of $90 \%$, but it may become vary from this according to the unlikely establishment results of the germination\% (EIAR, 2015); (Dawit Habte, 2017).

The field experiment was laid out in a split plot design. The treatments were replicated three times wherein three different seed sized varieties were allocated to primary factor and four plant density levels to secondary factor. Land preparation was done by tractor plough followed by harrowing.

The experiment consisted of 12 treatments with a total number of 36 plots. In accordance with the specification of the design, a field layout was prepared and each treatment was assigned randomly to experimental units within a

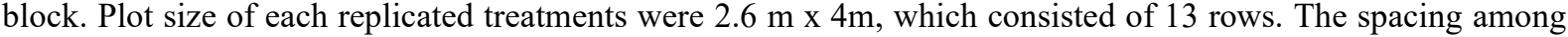
plots was $0.5 \mathrm{~m}, 20 \mathrm{~cm}$ between rows, and $1.0 \mathrm{~m}$ amongst blocks respectively. The outer four rows were reserved for border effect and the inner nine rows were for sampling and harvest area of biomass and grain yield.

\subsection{Agronomic Data Collection and Measurements}

These comprise seedling density, number of tillers per plant, days to heading, days to maturity, plant height, number of spikes, spike length, number of kernels per spike, grain yield, total dry bio mass yield, thousand kernels weight hecto liter weight, harvest index and grain protein content were considered as parameters to study the effect of the plant density on growth, yields and quality of bread wheat varieties. These growth and yield components were measured as the followings:

\subsection{Crop Phonology and Growth Parameters}

\subsubsection{Seedling Density}

Seedling density was recorded after two weeks from the middle rows of the net plot area of each treatment. This was done by using measuring quadrant meter in order to count randomly 5 times from selected row seedlings within the harvestable area. Finally, the mean values of five measuring were taken as number of seedlings.

2.6.2. Days To $50 \%$ of Heading

The number of days to attain $50 \%$ heading was recorded for individual plots when $50 \%$ of the plants reached to their reliable growing stages. This was done by observing randomly the heading shoots within the harvestable area. 2.6.3. Days To $90 \%$ of Physiological Maturity

The number of days to attain the physiological maturity was recorded for individual plots. It was taken when $90 \%$ of the plants in each plot reached maturity, i.e., when grains are difficult to divide by thumb nail. This was done by observing the color of the plot turned to yellow.

2.6.4. Number of Effective Tillers per Plant

The number of tillers per plant was recorded at individual plot levels. It was counted by hand in order to count randomly selected effective tillers within the harvestable area at physiological maturity.

2.6.5. Spike Length $(\mathrm{Cm})$

It was measured from five randomly selected spikes per net plot at physiological maturity and the mean value of five plants was taken as length of spikes.

It was taken five times from five randomly selected spikes per net plot at harvest and was averaged to per spike basis. After spikes had been measured from each of the five randomly selected central row plants, grains were separated from spikes to get the number of grains per spike. Finally, the mean value of five plants was taken as 
number of kernels per spike.

2.6.6. Plant Height $(\mathrm{cm})$

The plant height of five plants was recorded by measuring the plants from the surface of the soil to the tip of the spike own at physiological maturity and the average was calculated.

2.6.7. Number of Spikes $0.5 \mathrm{~m}$

Number of spikes was recorded five times (i.e. $5 \times 0.5 \mathrm{~m}=2.5 \mathrm{~m}^{-2}$ ) from the middle row of at harvest and was averaged to per $0.5 \mathrm{~m}$ length basis. This was done manually by trained workers in order to measure the plant stand percent in each of the plots. It was counted randomly from the selected row spikes within the harvestable area. Number of Spikes data is different from number of tillers data, because counting the number of tillers measures the tillering capacity per plants while number of spikes data measures the plants stand in each of the plots.

2.6.8. Thousand Kernels Weight (gm)

The thousand kernels weight (TKW) was determined by counting the grains by using an electronic counter and weighing 1000 kernels sampled from the net plot using a sensitive balance of precision $+0.001 \mathrm{~g}$. The thousand kernels weight was recorded after the grain was adjusted to $12.5 \%$ moisture content.

2.6.9. Hecto Liter Weight $(\mathrm{Kg} / \mathrm{hL})$

The hecto liter weight (HLW) was determined by measuring $1000 \mathrm{ml}$ kernel and weighing with the sensitive balance and then changed to $\mathrm{kg} / 1$ liter in order to measure the density of the grains powdering or milling capacity. 2.6.10. Bio Mass Yield $\left(\mathrm{kg} \mathrm{ha}^{-1}\right)$

Harvesting was done by hand using sickles. The Bio Mass Yield (BMY) was recorded from nine center rows after sun drying to a constant weight. Plants from each net plot area were manually harvested and sun dried in the open air. Dried plants were weighed to determine the biomass yield on plot basis and converted into hectare basis to determine total biomass yield per hectare.

2.6.11. Grain Yield $\left(\mathrm{kg} \mathrm{ha}^{-1}\right)$

The grain yield was measured by taking the weight of the grains threshed from the 9 center rows net plot area of each plot and converted to kilograms per hectare after adjusting the grain moisture content to $12.5 \%$.

2.6.12. Straw Yield $\left(\mathrm{kg} \mathrm{ha}^{-1}\right)$

Straw yield was calculated by subtracting grain yield from the corresponding biomass yield. It was expressed as $\mathrm{kg} \mathrm{ha}^{-1}$

2.6.13. Harvest Index (\%)

Harvest index values of each treatment were computed as the percent ratio of grain yield to the total biomass yield per plant from the respective treatments and expressed in percentile terms by using the formula of Donald as, $\mathrm{HI}=$ Grain yield ha $\mathrm{h}^{-1} /$ biological yield ha ${ }^{-1} \mathrm{x} 100$.

\subsection{Grain Quality}

2.7.1. Grain Protein Content (\%)

After threshing of sun dried plants from net plots, grain samples were taken for further protein content analysis. Protein content of wheat grains was analyzed by near Infrared Transmittance based Protein Analyzer (Model: Infratec 1241 grain analyzer). The GPC was recorded after the grain was adjusted to $12.5 \%$ moisture content. 2.7.2. Moisture Content (\%)

After threshing of sun dried plants from net plots, grain samples of $300 \mathrm{gm}$. were taken for further grain moisture tests and simultaneously the moisture content of the entire plots were determined by the Near Infrared Transmittance grain analyzer. The standard moisture level was taken as $12.5 \%$. The formula used for adjusting moisture percentage was used as: Conversion factor $(C F)=100-\mathrm{Y} / 100-12.5 \mathrm{X}$, where $\mathrm{Y}$ is the actual Moisture \% of the crop and $\mathrm{X}$ is the standard to which the yield is to be adjusted.

\subsection{Selected Physicochemical Properties of Experimental Soil Samples before Planting}

The amalgamated soil sample was made from samples collected at 0-30 cm surface from the experimental field before planting analyzed for some of their physical and chemical properties. In order to assess the general fertility status of the experimental field, composite soil samples were taken by using auger randomly from five spots of different plots in zigzag way just before planting, prior to fertilizer was applied to determine the initial nutrient status of the experimental field. The soil samples collected were air-dried, crushed and sieved to pass through $2 \mathrm{~mm}$ sieve for analysis of $\mathrm{pH}$, available $\mathrm{P}$ and through $1 \mathrm{~mm}$. sieve, were used for soil analysis determination of organic matter $(\mathrm{OM} \%)$, organic carbon $(\mathrm{OC} \%)$ content and total $\mathrm{N}$.

\subsection{Economic Benefits Evaluation}

In order to identify the most cost-effective bread wheat variety and profitable plant density level with low cost of production, the economic evaluation was carried out on the yield results. The average yield was adjusted 
downward by $15 \%$, assuming that farmers could get $15 \%$ less yield as per of CIMMYT (1988) technical manual. Total costs that varied for each treatment was calculated and treatments were ranked in order of ascending total cost that varied (TVC) and dominance analysis was used to eliminate treatments those costing more but producing a lower net benefit than the next lowest cost treatment.

The marginal rate of return (MRR) was calculated for each non-dominated treatment and a minimum acceptable marginal rate of return (MAMRR) of $100 \%$ was assumed. The prices of the inputs that were normal at the time of their use were considered for working out the cost of field preparation and planting activities. Net returns per hectare were calculated by deducting cost of production per hectare from gross income per hectare. Economic analysis was done using the prevailing market price for inputs at planting and for output at the time, when the crop was harvested. All cost and benefits were calculated on hectare basis in Ethiopian (ETB ha-1). For a treatment to be considered as a worthwhile option to farmers, the minimum acceptable rate of return (MARR) needs to be at least between 50 and 100\% (CIMMYT 1988). However, Birhan A. I., (2006) suggested a MARR of 100\% as realistic for Ethiopian case. Hence, MARR is considered $100 \%$ in this study.

2.9.1.Partial Budgeting Analysis

A partial budget analysis is a methodology by which a business managers, farmers or producers assesses whether a change in production practice will increase or decrease profit. It is evident that a partial budget analysis is however, does not determine profitability. Partial budgeting analysis determines only the change in profitability that would result from changing a production practices and hence, partial budget analysis was done to determine the economic impact of the recommended packages compared to the farmers' practice for bread wheat production at the study area. Local market (LM) price was used to calculate the product value.

2.9.2. Benefit Cost Ratio Evaluation (BCR)

The benefit-cost ratio is an indicator showing the relationship between the relative costs and benefits of the proposed research project. The benefit-cost ratio (BCR) analysis was used in the cost-benefit analysis in order to summarize the overall relationship between the relative costs and benefits of the conducted research project. If a project's BCR is less than 1.0, the project's costs outweigh the benefits, and it should not be considered. If the benefit value is higher than the cost the project is a good investment and hence, the higher the BCR the better the investment. $\mathrm{BCR}=$ Net Benefit Values $\div$ Total variable costs would give the benefit to costs ratios of the conducted activity or project. BCR can be a profitability index in profit contexts.

So, we accept all activities with a BCR greater than (1), when costs and benefits are discounted at the opportunity cost of benefit (Wiener, Jonathan B. 2013). The cost benefit analyses are undertaken keeping in mind the intended beneficiaries, the size of these beneficiaries and the quantitative value of the research result to them. $\mathrm{BCR}$ analysis is a technique that is well established in a project proposal and hence one with which planners is already familiar. It has the advantage of incorporating several criteria related to the economic efficiency and distribution into one or two measures. It requires a better understanding of economics than previous methods.

2.9.3. Statistical Data Analysis

All data collected were subjected to analysis of variance procedure using Excel-2016, SAS Version 9.2-2009 to summarize the collected row data and to make the economic evaluation and some graphical figures as well as the R-3.5.0 Studio-2018 software package that appropriate to the experimental design was used to analyze the summarized data using ANOVA procedures. A significance difference between treatments was outlined by LSD (Least Significance Difference) test at 5\% level of significance.

\section{RESULTS AND DISCUSSION}

\subsection{Physicochemical Status of the Soil at the Study Site}

The physical properties texture (sand, silt, and clay), including the chemical properties: $\mathrm{pH}$, organic carbon, total nitrogen and available phosphorus is displayed in (Table 3). The plow layer of the soil in the study area was a welldrained salty clay loam in texture which is largely developed from volcanic origin, predominantly basalt parent material and typically neutral in reaction.

Generally, the soil test values of some of the soil chemical properties considered in the laboratory analysis indicated that the soils of the study area were very poor in natural soil fertility especially in nitrogen and available phosphorus. In addition, the soils were very low in organic matter content which in turn influences significantly many of the most important soil physical and chemical properties including the release and availability of $\mathrm{N} \& \mathrm{P}$.

\subsection{Soil Analysis Results of the Experiment Site}

The soil analysis results are tabulated on (Table 3). The soil textural class of the experimental site was clay with the average soil particle size proportions of $48.32 \%$ clay, $24.22 \%$ silt and $27.46 \%$ sand according to hydrometer method of (Bouyoucus, 1951) and Tekalign (1991). Soil pH was measured using a glass combination $\mathrm{pH}$ meter in the supernatant solution of 1:2.5 soils to solution ratio of water (Van Reeuwijk, 1992).

Its $\mathrm{pH}$ value of the soil was $(\mathrm{pH}$ 6.698) which is almost neutral and within the optimum range for crop 
production. Determination of total nitrogen (N) content of the soil was $0.11 \%$ (Table 3 ), which can have classified as very medium as stated by Kjeldahl digestion and 30 distillations method (Jackson, 1958).

The available $\mathrm{P}$ was extracted following the procedure described by Olsen et al., (1954), and its content was 2.574 (ppm), which have classified as medium. According to London J. R. (1991) the exchangeable bases in sufficient range with low soil organic carbon content for crop production. As much as the soil organic carbon (OC) is concerned, its percentile value was about $1.88 \%$, which was within the range of low organic carbon content (Walkley \& Black, 1934).

Table 3. The Soil Characteristics of the Study Area before Planting

\begin{tabular}{|c|c|c|c|c|c|c|c|c|c|}
\hline \multicolumn{5}{|c|}{ Physical properties } & \multicolumn{5}{|c|}{ Chemical properties } \\
\hline \multirow{2}{*}{$\begin{array}{c}\text { Soil } \\
\text { Depth }\end{array}$} & \multicolumn{3}{|c|}{ Particle Size (\%) } & \multirow{2}{*}{$\begin{array}{c}\text { Soil } \\
\text { Texture } \\
\text { Class }\end{array}$} & \multirow{2}{*}{$\begin{array}{l}\text { Available P } \\
(\mathrm{ppm})\end{array}$} & \multirow{2}{*}{$\begin{array}{l}\mathrm{pH} \text { in } \\
\text { water } \\
(1: 2.5)\end{array}$} & \multirow{2}{*}{$\begin{array}{l}\text { Total } \\
\text { N \% }\end{array}$} & \multirow[t]{2}{*}{$\mathrm{OC} \%$} & \multirow[t]{2}{*}{$\mathrm{OM} \%$} \\
\hline & Sand & Silt & Clay & & & & & & \\
\hline $0-30$ & 27.46 & 24.22 & 48.32 & Silty clay loam & 2.5 & 6.69 & 0.11 & 1.88 & 3.25 \\
\hline
\end{tabular}

Note: $\mathrm{P}=$ Phosphorus, $\mathrm{pH}=$ Potential Hydrogen, $\mathrm{N}=$ Nitrogen, $\mathrm{OC}=$ Organic Carbon, $\mathrm{OM}=$ Organic Matter

\subsection{The Soil Characteristics of the Study Area}

According to the results of soil analysis the soil characteristics at the study site for average proportions of clay, silt, sand, available phosphorus (ppm), $\mathrm{PH}$, Nitrogen $\%$, available soil $\mathrm{OC} \%$ and $\mathrm{OM} \%$ at planting time are presented in (Table 3).

Table 4. Analysis of Variance Table for Growth, Grain Yield and Yield Components of Bread Wheat Mean Square

\begin{tabular}{|c|c|c|c|c|c|c|c|c|c|c|c|}
\hline Source & $\begin{array}{l}\text { Degree of } \\
\text { Freedom }\end{array}$ & $\begin{array}{l}\mathrm{S} \\
\mathrm{N}\end{array}$ & DH & $\mathrm{M}$ & NT & SL & TKW & $\mathrm{Hl}$ & SY & $\begin{array}{l}\mathrm{B} \\
\mathrm{Y}\end{array}$ & GY \\
\hline & & 10.7 & 0.19 & 4.5 & 0.86 & 3.00 & 7.0 & 0.76 & 1647 & 22268 & 102422 \\
\hline Rep & 2 & 5 & 44 & 28 & 11 & 0 & $\begin{array}{l}26 \\
73 .\end{array}$ & 7 & 1425 & 859 & 19.219 \\
\hline Variety/S & & 113. & 3.36 & & 24.6 & 6.08 & 14 & 37.1 & 1441 & 10910 & \\
\hline $\mathrm{S}$ & 2 & $\begin{array}{c}25 \\
9.87\end{array}$ & $\begin{array}{c}11 \\
0.61\end{array}$ & $\begin{array}{l}181 \\
4.4\end{array}$ & $\begin{array}{l}944 \\
0.36\end{array}$ & $\begin{array}{c}33 \\
1.33\end{array}$ & 4 & $\begin{array}{c}23 \\
2.47\end{array}$ & $\begin{array}{l}5964 \\
8617\end{array}$ & $\begin{array}{c}430 \\
86667\end{array}$ & 28591985.408 \\
\hline Error-a & 4 & $\begin{array}{c}5 \\
26.7\end{array}$ & $\begin{array}{c}11 \\
0.39\end{array}$ & $\begin{array}{l}44 \\
0.1\end{array}$ & $\begin{array}{c}11 \\
0.10\end{array}$ & $\begin{array}{c}33 \\
0.47\end{array}$ & $\begin{array}{l}9.7 \\
2.8\end{array}$ & $\begin{array}{c}8 \\
1.03\end{array}$ & $\begin{array}{c}605 \\
4565\end{array}$ & $\begin{array}{c}725 \\
42845\end{array}$ & $\begin{array}{l}74961825.645 \\
222688\end{array}$ \\
\hline PD & 3 & $\begin{array}{c}69 \\
13.4\end{array}$ & $\begin{array}{c}81 \\
0.95\end{array}$ & $\begin{array}{l}02 \\
0.1\end{array}$ & $\begin{array}{c}19 \\
0.10\end{array}$ & $\begin{array}{c}22 \\
0.19\end{array}$ & $\begin{array}{l}63 \\
1.0\end{array}$ & $\begin{array}{c}3 \\
1.09\end{array}$ & $\begin{array}{l}9985 \\
5297\end{array}$ & $\begin{array}{c}795 \\
51402\end{array}$ & $\begin{array}{l}59197.95 \\
109104\end{array}$ \\
\hline SS:PD & 6 & $\begin{array}{c}35 \\
3.90\end{array}$ & $\begin{array}{c}37 \\
0.65\end{array}$ & $\begin{array}{l}02 \\
0.2\end{array}$ & $\begin{array}{c}19 \\
0.04\end{array}$ & $\begin{array}{c}44 \\
0.59\end{array}$ & $\begin{array}{l}28 \\
1.8\end{array}$ & $\begin{array}{c}8 \\
1.66\end{array}$ & $\begin{array}{l}2342 \\
1746\end{array}$ & $\begin{array}{c}828 \\
18222\end{array}$ & $\begin{array}{l}30 \quad 255.29 \\
866677\end{array}$ \\
\hline Error-b & 18 & 7 & 74 & 13 & 63 & 26 & 77 & 5 & 6576 & 398 & 33.381 \\
\hline
\end{tabular}

Note: $\mathrm{PD}=$ Plant Density, $\mathrm{SS}=$ Seed Size, $\mathrm{SN}=$ Seedling Number, $\mathrm{DH}=$ Days to Heading, DM=Days to Maturity

N T=Number of Tillers, SL=Spike Length, TKW=Thousand Kernel Weight, HLW=Hecto Liter Weight $\mathrm{SY}=$ Straw Yield, BY=Biomass Yield, GY=Grain yield, HI=Harvest Index

\subsection{Bread Wheat Agronomic Parameters and Yield Components}

The major agronomic parameters such as number of seedling, number of effective tillers, plant height, days to heading, days to maturity, number of spikes, number of seeds per spike, grain quality and yield components comprising protein content in grain, total above ground dry biomass yield, 1000 grains weight, hecto liter weight and harvest index respectively, were measured as well for this study.

\subsection{The Main Effect of the Varieties Seed Size}

Analysis of variance showed that the main effect of varieties had significant effect $(\mathrm{P}<0.05)$ on days to $50 \%$ of heading, days to $90 \%$ of maturity, thousand kernel weight and hectoliter weight, whereas number of tillers, spike length number of kernels, plant height and grain protein content were not significantly $(\mathrm{p}<0.05)$ affected by varieties (Table $5 \& 6$ ).

3.4.1. Number of Effective Tillers Plant ${ }^{-1}$

Tillering capacity is one of the determining components for bread wheat yielding ability. Tillers number was less significantly $(\mathrm{P}<0.1)$ varied among the varieties. The highest number of effective tillers per plant $(28.33)$ was obtained from the variety Dendea/medium seed size/ at seed rate of 400 plants $\mathrm{m}^{-2}$ seed rates while; the lowest numbers of effective tillers plant ${ }^{-1}$ (16.33) were obtained from the variety Shorima at seed rate of 400 
plants $\mathrm{m}^{-2}$. Such increment in number of effective tillers due to increasing plant density could be attributed to increasing number of plants per plot and also tillering capacity. On the other hand, the lower number of tillers for variety Dendea/medium seed size/ might be attributed to the death of tillers due to low rainfall late in the growing season. The analysis of variance indicated that the main effect of varieties had highly significant effect $(\mathrm{P}>0.05)$ on the number of tillers.

Tillering pattern of wheat cultivars may vary according to their genetic makeup and per plant availability of space on average, but it is well recognized that increase in tillering influence the grain yield. The analysis of variance demonstrated significant $(\mathrm{P}<0.05)$ effect of the varieties seed size on number of tillers/plant. The number of tillers plant ${ }^{-1}$ as relatively higher $(8.67)$ in variety Shorima/small seed size/ as compared to variety Dendea/medium seed size/ (6.33) and both of these varieties showed similar tillering pattern. However, wheat seedlings emerged from the large size seeds resulted in more number of tillers (8.67) as compared to those from small size seeds $(7.00-7.33)$. This suggests that the larger seeds produced healthier seedlings having higher tillering capacity as compared to the plants developed from smaller sized seeds. The overall results suggested that quality seed in wheat can influence the tillering pattern in positive direction.

3.4.2. Days to $50 \%$ of Heading

The mean difference in days to heading recorded from the variety Dendea/medium seed size/ was significantly higher $(\mathrm{p} \leq 0.01)$ than the mean difference of the variety Hidassie/large seed size/ and Shorima/small seed size/, while the mean difference in days to heading recorded from the variety Hidassie was significantly $(\mathrm{p}<0.01)$ lower than the variety Shorima/small seed size/ and Dendea/medium seed size/. The mean days to heading were also significantly differed due to the varieties genetic makeup but no significantly $(\mathrm{p}>0.05)$ different owing to the plant density treatments (Table 5). The analysis of variance indicated that the main effect of varieties had significant $(\mathrm{p}<0.01)$ effect on days to $50 \%$ of heading. But the plant density treatments had not affecting days to heading. This is because, the plant density levels were converted and adjusted to seed rate levels depending on the varieties seed size using by seed rate manipulating formula, and that is why the plant density was not affected the days to heading. The findings by Gafaar (2007) also indicated that increasing plant density from 200 up to 400 grains per meter square in wheat crop significantly decreased the days to $50 \%$ of heading. Furthermore, Worku Awdie (2008) concluded that increasing the levels of seeding rate decreased the days to heading consistently.

Table 5. Main Effect of Varieties on Number of Tillers, Days to 50\% of Heading, Days to $90 \%$ of Maturity and Spike Length.

\begin{tabular}{|c|c|c|c|c|c|}
\hline Varieties/Seed & $\begin{array}{l}\text { Number of } \\
\text { Effective } \\
\text { Tillers Plant } \\
1\end{array}$ & $\begin{array}{c}\text { Days to } 50 \% \text { of } \\
\text { Heading }\end{array}$ & $\begin{array}{l}\text { Days to } 90 \% \text { of } \\
\text { Maturity }\end{array}$ & $\begin{array}{l}\text { Spike Length } \\
(\mathrm{cm})\end{array}$ & $\begin{array}{l}\text { Number of } \\
\text { Kernels/ } \\
\text { Spike }\end{array}$ \\
\hline Shorima/Small Sized & $8.0^{\mathrm{a}}$ & $65.0^{\mathrm{b}}$ & $117.0^{\mathrm{a}}$ & $8.5^{\mathrm{a}}$ & $35.0^{\mathrm{a}}$ \\
\hline Dendea/Medium Sized & $7.0^{\mathrm{a}}$ & $69.0^{\mathrm{a}}$ & $118.0^{\mathrm{a}}$ & $7.7^{\mathrm{a}}$ & $\begin{array}{l}38.0^{\mathrm{a}} \\
37.0^{\mathrm{a}}\end{array}$ \\
\hline Hidassie/Large Sized & $7.5^{\mathrm{a}}$ & $63.0^{\mathrm{c}}$ & $116.0^{\mathrm{b}}$ & $7.5^{\mathrm{a}}$ & 6.58 \\
\hline LSD & 1.14 & 3.07 & 0.87 & 1.68 & 12.40 \\
\hline $\mathrm{CV} \%$ & 10.23 & 3.30 & 0.50 & 14.90 & $0.310 \mathrm{~ns}$ \\
\hline$(\mathrm{P}<0.05)$ & $0.05^{*}$ & $0.002 * *$ & $0.0008 * * *$ & $0.005 * *$ & \\
\hline
\end{tabular}

Note: Means with the same letter(s) in the same column of each trait are not significantly different $*, * *$ and $* * *$ indicates significant at $10 \%, 5 \%$, probability level, respectively.

3.4.3. Days to $90 \%$ of Maturity

The mean difference in days to maturity recorded from the variety Dendea was significantly higher $(p \leq 0.01)$ than the mean difference of the variety Hidassie and Shorima, while the mean difference in days to maturity recorded from the variety Hidassie was significantly $(p<0.01)$ lower than the variety Shorima and Dendea. The mean days to maturity were also significantly differed due to the varieties but not significantly $(p>0.05)$ different owing to the plant density treatments (Table 5). The analysis of variance indicated that the main effect of varieties had significant $(p<0.01)$ effect on days to $90 \%$ physiological maturity. The plant density had not affecting days to maturity. This is because, the plant density levels were converted and to seed rate levels depending on their seed size using by seed rate manipulating formula, and that is why the plant density was not affected the days to maturity. Therefore, it cannot be predictable significant $(\mathrm{p}>0.05)$ variations in the days to maturity and even from some other inclusive agronomic traits.

The delay in the maturity periods of bread wheat with the treatments combination attributed to the increased days to seed emergence period due to a slight shortage of rainfall shower at planting time. The Variety Hidassie followed by the variety Shorima took significantly shorter days to maturity as compared to the variety Dendea in which the means in days to maturity recorded from the variety Hidassie resulted in somewhat, late days to maturity 
(Table 5).

3.4.4. Spike Length (cm)

Spike length is a character of great significance that contributes to grain yield per unit area considerably. The spike length of the varieties Hidassie /large seed size/ and Dendea/medium seed size/ as affected by seed size is presented in Table 5. The variance analysis result indicated that the differences in the spike length due to varieties was statistically significant $(\mathrm{P}<0.01)$. It is evident from the results that the spike length was markedly higher $(9.0$ $\mathrm{cm})$ in variety Shorima/small seed size/ than variety Hidassie/large seed size/ $(7.0 \mathrm{~cm})$, and differences between these values were statistically significant; suggesting that variety Shorima/small seed size/ is genetically superior to Hidassie/large seed size/ for spike length character.

The length of spike plays a vital role in wheat towards the grains spike $e^{-1}$ and finally the yield (Shahzad et al., 2007). The crop sown with small size seeds produced spikes of greater in length $(9.0 \mathrm{~cm})$ and large size seeds produced spikes of less in length $(7.0 \mathrm{~cm})$ on average as compared to the crop sown with medium size seeds produced spikes of intermediate in length $(7.67-8.67 \mathrm{~cm})$. As far as the seed size are concerned, highly significant $(\mathrm{p}<0.01)$ difference was recorded for the spike length.

The variety Shorima/small seed size/ produced the longest spike length of $9.0 \mathrm{~cm}$ while, while variety Hidassie/large seed size/ produced the shortest spike length of $7.0 \mathrm{~cm}$. This result was in agreement with those of (Otteson et al., 2007 and Otteson, B.N., M. 2008) who reported that individual genotypes responded differently to spike length for different varieties of wheat. Khan et al., (2001) reported that varieties have different genetic potential regarding the spike length.

Table 6. Main Effect of Varieties on Number of Spike, Thousand Kernel Weight and Hecto Liter Weight

\begin{tabular}{lccc}
\hline Varieties/Seed Size & Number of Spike/50 $(\mathrm{cm})$ & TKW $(\mathrm{gm})$. & HLW $(\mathrm{kg} / \mathrm{hL})$ \\
\hline Shorima Small Sized Seeds & $39.41 \mathrm{a}$ & $41.68^{\mathrm{b}}$ & $79.77^{\mathrm{a}}$ \\
Dendea Medium Sized Seeds & $38.50 \mathrm{a}$ & $42.80^{\mathrm{ab}}$ & $76.26^{\mathrm{b}}$ \\
Hidassie Large Sized Seeds & $39.08 \mathrm{a}$ & $48.22^{\mathrm{a}}$ & $78.30^{\mathrm{ab}}$ \\
\hline LSD & 8.24 & 4.53 & 2.29 \\
CV $\%$ & 14.50 & 7.10 & 2.00 \\
$(\mathrm{P}<0.05)$ & $0.924 \mathrm{~ns}$ & $0.044^{*}$ & $0.014^{*}$ \\
\hline
\end{tabular}

Means with the same letter(s) in the same column of each trait are not significantly different $*, * *$ and $* * *$ indicates significant at $10 \%, 5 \%$, probability level, respectively.

3.4.5. Thousand Kernels Weight (gm)

Thousand kernels weight (TKW) is a quality parameter to assess the grain quality in wheat and this trait is generally influenced by genetic makeup of varieties due to the effect that the variable plant density rates used for each varieties depending on their seed sizes. The analysis of variance indicated that the varieties had significant $(\mathrm{P}<0.05)$ influence on thousand kernels weight. The plant density had not affecting the TKW weight.

The TKW of the variety Hidassie $(46.41 \mathrm{gm})$ and Dendea $(42.80 \mathrm{gm})$ were significantly $(\mathrm{P}<0.05)$ higher than the variety Shorima (41.68 gm.) suggesting that the grains of Hidassie are bolder and heavier than those of variety Shorima and Dendea as shown on (Table 6). This could be due to the late maturity of variety Shorima/small seed size/ which might have suffered from unfavorable environmental condition late in the growing season. In addition, high density caused to increasing number of spikes and as a result competition would increase and little photosynthesis would be available to grain filling and finally thousand kernels weight would reduce due to high plant density. Chaudhary et al., (2000) reported that, low seed rates significantly increased thousand kernels weight. Similarly, (Jan et al., 2000) reported that, as the seeding rate was increased, the number of plants emerged per unit area also increased but thousand seed weight decreased in wheat crop. Khan et al., (2002) and Mehrvar and Asadi (2006) concluded that, by increasing seed rate the thousand grains weight was reduced in wheat.

3.4.6. Hecto Liter Weight $(\mathrm{Kg} / \mathrm{hL})$

The analysis result showed that a significant difference on the hecto liter weight (HLW) was observed among the bread wheat varieties. The highest hecto liter weight $(79.77 \mathrm{~kg} / \mathrm{hL})$, was obtained from the variety Shorima, followed by the variety Hidassie $(78.09 \mathrm{~kg} / \mathrm{hL})$. The lowest HLW $(76.26 \mathrm{~kg} / \mathrm{hL})$ was recorded from the variety Dendea as shown on (Table 6). With reference to the report of (MoARD, 2010), the present study results obtained from the variety Dendea was lower than the HLW result indicated on the report of (MoARD, 2010), as compared with which reported in this report that the HLW of the variety Dendea was $(76.26 \mathrm{~kg} / \mathrm{hL})$. This should be due to the effect that the varying seed rates used under this study. Likewise, (Bordes et al., 2008) reported that some varieties have inherently higher HLW than others when grown under the same conditions.

On the other hand, HLW was ranged from $76.26-79.77 \mathrm{~kg} / \mathrm{hL}$ for the varieties under this study which was in agreement slightly with (Atwell, W.S., Finnie A., 2001), who reported that, hectoliter weight may range from about $(57.9 \mathrm{~kg} / \mathrm{hL})$ for a poor wheat to about $82.4 \mathrm{~kg} / \mathrm{hL}$ for a sound bread wheat. Considering the main effect of 
varieties, hectoliter weight was showed that a significant difference on the hecto liter weight (HLW) among the bread wheat varieties due to the effect that the varying seed rates used under this study for each varieties depending on their seed sizes.

In view of that, the lowest hectoliter weight $(76.26 \mathrm{~kg} / \mathrm{hL})$ was observed from the variety Dendea and the highest HLW $(79.77 \mathrm{~kg} / \mathrm{hL})$ was observed from the variety Shorima, are significantly different from each other. Similar result was obtained by (Bavec et al., 2002) who reported that increasing plant density levels ranging from $350-800$ seeds $\mathrm{m}^{-2}$ significantly decreased in bread wheat. The present study was also in line with (Tayyar, 2010) who reported that hectoliter weights of the varieties were significantly influenced by genotype which means a group of cultivars having the same genetic composition.

\subsection{The Main Effects of the Plants Density}

The analysis of variance results indicated that number of seedlings and harvest index had highly significant effect $(p<0.01)$ on plant density (Table 6). This should be due to the effect that the varying plant density rates used under this study.

Since the plant density levels were adjusted based on their seed size by using seed rates computing formula, it cannot be expected significant $(p<0.05)$ variations from the whole agronomic traits. As a result, increasing or decreasing levels of plant density consistently among the different seed sizes were not affected most of the agronomic traits except the number of seedling and harvest index. This implies that adjusted seed rates with recommended plant density levels based on their seed size should not produce significant differences on certain traits.

3.5.1. Number of Seedlings per $0.5 \mathrm{~m}$

The analysis of variance revealed that the main effect of plant density had highly significant effect $(p<0.01)$ on seedling numbers, but not significantly $(\mathrm{p}>0.05)$ differed owing to some other traits. This is because, the plant density levels were converted to seed rate levels depending on their seed size using by seed rates manipulating formula, essentially aimed at fulfilling the subsequent objective of this study that in order to identify the most cost-effective bread wheat varieties with low cost and more beneficial crop production practices.

As a result, that is why the plant density is not affected some all other non-significant traits. So it cannot be predictable significant $(\mathrm{p}>0.05)$ variations even from some other inclusive agronomic traits. The highest seedling number (28.00) was counted from variety Dendea at seed rate of (400 seeds $\mathrm{m}^{-2}$ ), whereas the lowest seedling number (16.00) was counted from variety Shorima at seed rate of 250 seeds $\mathrm{m}^{-2}$.

The significant $(\mathrm{P}<0.01)$ differences in seedling numbers were observed due to the variable plant density rates and hence, number of seedlings was significantly affected by the plant density levels. The analysis of variance indicated that the main effect of plant density had highly significant effect $(\mathrm{P}<0.01)$ on number of seedlings.

Table 7. Main Effect of Grain Yield, Plant Density on Number of Seedling \& Harvest Index of Bread Wheat

\begin{tabular}{cccc}
\hline Plant Density & $\begin{array}{c}\text { Grain Yield } \\
(\mathrm{kg} / \mathrm{ha})\end{array}$ & $\begin{array}{c}\text { Number of Seedlings per } \\
0.5 \mathrm{~m}\end{array}$ & $\begin{array}{c}\text { Harvest } \\
\text { Index } \%\end{array}$ \\
\hline 250 Plants m $^{-2}$ & $4207.0^{\mathrm{a}}$ & $19.56^{\mathrm{b}}$ & $22.70^{\mathrm{bc}}$ \\
300 Plants m $^{-2}$ & $4392.8^{\mathrm{a}}$ & $22.00^{\mathrm{ab}}$ & $30.98^{\mathrm{a}}$ \\
350 Plants m $^{-2}$ & $4150.1^{\mathrm{a}}$ & $22.44^{\mathrm{a}}$ & $29.64^{\mathrm{ab}}$ \\
400 Plants m $^{-2}$ & $4091.7^{\mathrm{a}}$ & $23.67^{\mathrm{a}}$ & $21.84^{\mathrm{c}}$ \\
\hline LSD & 550.94 & 2.63 & 7.69 \\
CV\% & 9.80 & 9.00 & 22.00 \\
$(\mathrm{P}<0.05)$ & $0.462 \mathbf{n s}$ & $0.003^{* *}$ & $0.005^{* *}$
\end{tabular}

Note: Means with the same letter(s) in the same column of each trait are not significantly different $*, * *$ and $* * *$ indicates significant at $10 \%, 5 \%$, probability level, respectively.

3.5.2. Harvest index \%

The analysis of variance regarding the harvest index showed that there was significant difference due to the main effect of plant density level. Highest harvest index was recorded from the seed rate of 300 and $350 \mathrm{plants} \mathrm{m}^{-2}$ (30.98\% and 29.64\%) respectively as shown on (Table 7). The statistical results revealed that the main effect of plant density had significant effect $(\mathrm{p}<0.01)$ on harvest index. According to the study results of Abiot M., (2017), the ability of a cultivar to convert the dry matter into economic yield is indicated by its harvest index. The higher the harvest index value, the greater the physiological potential of the crop for converting dry matter to grain yield. The analysis of variance showed that harvest index was significantly $(\mathrm{p}<0.01)$ affected by plant density.

The highest harvest index (30.98\%) was obtained at seeding rate of 300 seeds $\mathrm{m}^{-2}$, while the lowest harvest 
index $(21.84 \%)$ was recorded at seeding rate of 400 seeds $\mathrm{m}^{-2}$. Similar with the present finding, Iqbal et al., (2012) stated that highest harvest index obtained at seeding rate of $150 \mathrm{~kg} \mathrm{ha}^{-1}$ as compared to 125 and $175 \mathrm{~kg} \mathrm{ha}^{-1}$. Harvest index had interrelationship with grain yield and above ground biomass yield that the highest harvest index was the result of greater grain yield. Abiot M., (2017) reported that lowest harvest index was mainly due to increased plant height and increased biomass yield excessively rather than grain yield which lead to decrease of harvest index. Generally speaking, the main effect of the plant density on number of seedling and harvest index indicated significant $(\mathrm{p}<0.01)$ variations in response to different seed rates of bread wheat.

\subsection{The Interaction Effects of the Varieties Seed Size and Plants Density Levels}

The analysis of variance revealed that the interaction effect of varieties and plant density had significant $(p<0.05)$ effect on seedling numbers, straw yield, biomass yield, while on grain yield showed highly significant $(p<0.001)$ variations, like wise on harvest index indicated very highly significant $(p<0.001)$ variations. The remained agronomic traits indicated non- significant $(\mathrm{p}>0.05)$ variations due to the factors interactions.

3.10.1. Number of Seedlings per $0.5 \mathrm{~m}$

There were significant interaction effects of varieties and plant density on number of seedlings. The highest

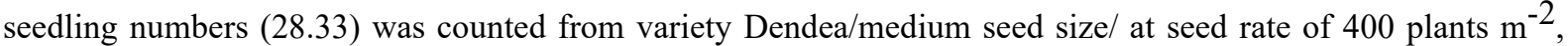
whereas the lowest seedling number 16.33 was counted from the variety Shorima/small seed size/at seed rate of 250 plants $\mathrm{m}^{-2}$ as shown on (Table 8 ). The analysis of variance indicated that the interaction effect of the varieties seed size and plant density had significant $(p<0.05)$ effect on number of seedlings seedling numbers were significantly affected $(\mathrm{p} \leq 0.05)$ by the interactions among the varieties seed size. In line with the research results of A. Zareian, L., et al., (2012), the varieties seed size had significant impact on the entire of tested traits with the exclusion of thousand seeds weight results showed that number of seeds per spike significantly decreased by increasing the varieties seed size. The other characters revealed significant rise by rising seed size. Varieties had significant result on thousand seeds weight, but other characters were alike amongst varieties.

3.10.2. Straw Yield $\left(\mathrm{kg} \mathrm{ha}^{-1}\right)$

The interaction effect of varieties and plant density levels significantly $(\mathrm{p}<0.05)$ affected straw yield as shown on (Table 8). The highest ( $18851.33 \mathrm{~kg} \mathrm{ha}^{-1}$ ) straw yield was observed at seeding rate of $250 \mathrm{plants}^{-2}$ while the lowest $\left(6095.00 \mathrm{~kg} \mathrm{ha}^{-1}\right)$ straw yield was found with seeding rate of 350 plants $\mathrm{m}^{-2}$ as shown on (Table 8). This might be due to the fact that an erratic seeding rate had proper nutrient utilization and hence resulted in vigorous plant density and leads to greater plant height which can produce a higher straw yield. This result is in contrast with Worku Awdie (2008) and Ali (2010) who exhibited that as seeding rate increased, correspondingly straw yield increased due to higher stand number at crop establishment period. The results of the study indicated that the interaction effects of varieties and plant density were significantly $(\mathrm{p} \leq 0.05)$ affected the straw yield of bread wheat (Table 8). According to the analysis of variance, averaged over varieties, highest straw yield $\left(18851.33 \mathrm{~kg} \mathrm{ha}^{-1}\right)$ followed by $16855.33 \mathrm{~kg} \mathrm{ha}^{-1}$ ) was obtained from the variety Hidassie at the lowest and medium plant density levels of 250 and 350 plants $\mathrm{m}^{-2}$ respectively. The lowest straw yield (6095.00 $\left.\mathrm{kg} \mathrm{ha}^{-1}\right)$ was obtained from variety Dendea at seed rate of 350 plants $\mathrm{m}^{-2}$. This showed that the large seed sized variety Hidassie is superior in straw production than the medium and small seed sized bread wheat varieties of Dendea and Shorima respectively. In general, the interaction effect of the varieties seed size and plant density was found to be statistically $(p<0.05)$ significant on straw yield.

3.10.3. Biomass Yield $\left(\mathrm{kg} \mathrm{ha}^{-1}\right)$

Biomass yield represents overall growth performance of the plant as well as the crop is considered to be the essential yield parameter to get useful information about overall growth of the crop. Biomass yield is highly motivated by crop nutrition (own observation). Analysis of variance showed that the interaction effect of the varieties and plant density had significant $(\mathrm{p}<0.05)$ effect on the above ground dry biomass yield. The highest biomass yield $\left(23407.00 \mathrm{~kg} \mathrm{ha}^{-1}\right.$ ) was gained from the variety Hidassie/large seed size/ at the seeding rate of 250 plants $\mathrm{m}^{2}$ followed by the biomass yield $\left(20631.00 \mathrm{~kg} \mathrm{ha}^{-1}\right)$ was gained from the variety Dendea at a seeding rate of 400 plants $\mathrm{m}^{-2}$ while lowest biomass yield $\left(16197.00 \mathrm{~kg} \mathrm{ha}^{-1}\right)$ was obtained from the variety Shorima at the seeding rate of 350 plants $\mathrm{m}^{-2}$ (Table 8 ). The increased in biomass production might be attributed to the increased plant density due to higher seeding rate and taller plants.

The present result is in agreement with the finding of Zewdie Bishaw et al., (2014) who reported a positive association between biomass yield and plant height, thus taller plants resulted higher biomass yield. Similar with the present finding, Jemal Abdulkerim et al., (2015) also reported that higher biomass yield was recorded on increased seeding rates of 200 and $175 \mathrm{~kg} \mathrm{ha}^{-1}$. Similarly, Iqbal et al., (2012) also found that biological yield was 
increased as seeding rate increased from $125 \mathrm{~kg} \mathrm{ha}^{-1}$ to 150 and $175 \mathrm{~kg} \mathrm{ha}^{-1}$. Moreover, Seleiman et al. (2010) confirmed that increasing seeding rates up to 350 or 400 plants $\mathrm{m}^{-2}$ increased grain, straw and biomass yields. The above ground dry biomass yield $\left(\mathrm{kg} \mathrm{ha}^{-1}\right)$ refers to the total dry matter accumulation of a plant system and biological yield is also referred to as gross yield that is the yield obtained before any losses occur during and after harvest (Iqbal et al., 2012).

The results of this study relating to the yield/ha of the varieties Shorima/Small seed size, Dendea/medium seed size/ and Hidassie/large seed size/ as influenced by the varieties seed size and plant density are presented in (Table-8). The analysis of variance suggested that the biological yield of bread wheat was not significantly $(\mathrm{P}<0.05)$ affected by the varieties seed size, while the interaction effect of the varieties seed size and plant density was statistically $(\mathrm{P}>0.05)$ significant.

Table 8. Interaction Effect of Varieties \& Plant Density on Yield \& Yield Components of Bread Wheat

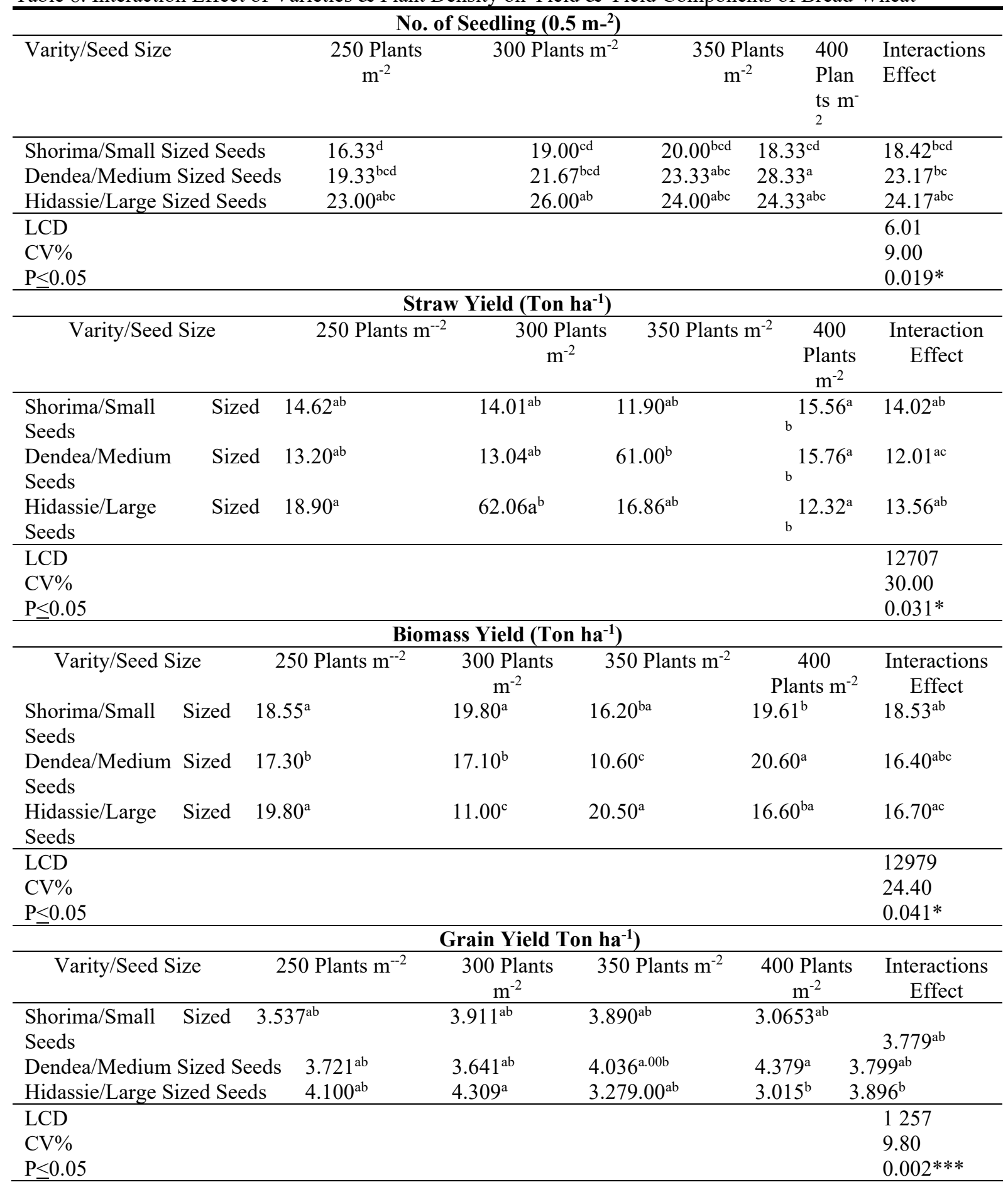




\begin{tabular}{|c|c|c|c|c|c|}
\hline \multicolumn{6}{|c|}{ Harvest Index $\%$} \\
\hline Varity/Seed Size & $250 \mathrm{Pla}$ & $\begin{array}{c}300 \text { Plants } \\
\mathrm{m}^{-2}\end{array}$ & 350 Plants $\mathrm{m}^{-2}$ & $\begin{array}{c}400 \\
\text { Plan } \\
\text { ts } \mathrm{m}^{-} \\
2\end{array}$ & $\begin{array}{c}\text { Interactions } \\
\text { Effect }\end{array}$ \\
\hline $\begin{array}{l}\text { Shorima/Small } \\
\text { Sized Seeds }\end{array}$ & $2.93^{\mathrm{c}}$ & $24.37^{\mathrm{c}}$ & $28.63^{\mathrm{abc}}$ & $21.13^{c}$ & $19.27^{\mathrm{c}}$ \\
\hline $\begin{array}{l}\text { Dendea/Medium } \\
\text { Sized Seeds }\end{array}$ & $25.77^{b c}$ & $24.97^{b c}$ & $42.33^{\mathrm{ab}}$ & $24.20^{\mathrm{c}}$ & $29.31^{\mathrm{ac}}$ \\
\hline $\begin{array}{l}\text { Hidassie/Large } \\
\text { Sized Seeds }\end{array}$ & $19.40^{c}$ & $44.05^{\mathrm{a}}$ & $17.97^{\mathrm{c}}$ & $20.20^{\mathrm{c}}$ & $25.30^{\mathrm{bc}}$ \\
\hline LCD & & & & & 17.57 \\
\hline $\mathrm{CV} \%$ & & & & & 22.0 \\
\hline $\mathrm{P} \leq 0.05$ & & & & & $0003 * *$ \\
\hline
\end{tabular}

Note: Means with the same letter(s) in the same column of each trait are not significantly different $*, * *$ and $* * *$ indicates significant at $10 \%, 5 \%$, probability level, respectively

3.10.4. Grain Yield $\left(\mathrm{kg} \mathrm{ha}^{-1}\right)$

The analysis of variance showed that the interaction effect of varieties and plant density had significant effect $(\mathrm{P}<0.01)$ on grain yield. The highest average grain yield $\left(4866 \mathrm{~kg} \mathrm{ha}^{-1}\right)$ was obtained from the variety Dendea at the seeding rate of 400 plants $\mathrm{m}^{-2}$ followed by the average grain yield (4788.00 $\mathrm{kg} \mathrm{ha}^{-1}$ ) was obtained from the variety Hidassie at the seeding rate of 300 plants $\mathrm{m}^{-2}$ and the lowest average grain yield $\left(3350.00 \mathrm{~kg} \mathrm{ha}^{-1}\right) \mathrm{was}^{-1}$ obtained from the variety Hidassie at plant density rate of 400 plants $\mathrm{m}^{-2}$ (Table 10). The results relating to grain yield obtained from bread wheat varieties of Shorima, Dendea and Hidassie were influenced by the interaction effect of varieties and plant density.

Based on the result of variance analysis, increasing seeding rate results in increasing grain yield using by an extreme seed rate, but which were taken the highest seed costs as shown on (Table 8), and hence, the economic analysis of this study shows the vice-versa results due to using the maximum cost of production of an extreme seed rate. The current results of grain yield are agree with those of Hameed et al., (2003) and Ijaz et al., (2003), who reported that grain yield increased as seed rate increased. The partial budgeting analysis showed that, the highest net benefit was obtained from the treatment combination of variety Hidassie at plant density of 300 plants $\mathrm{m}^{-2}$, by using of the lowest seed rate with a low cost of production (Table 10). According to CIMMYT (1988), yield alone does not reflect much about efficiency of production and hence, its production efficiency has been examined by partial budget analysis.

Similarly, Worku Awdie (2008) and Hussain et al., (2010) reported that grain yield increased as seeding rate was increased from 50 to 150 and from 100 to $150 \mathrm{~kg} \mathrm{ha}^{-1}$, respectively. Moreover, Ali et al., (2010) concluded that the three years average data showed that grain yield was superior at seeding rate of $150 \mathrm{~kg} \mathrm{ha}^{-1}$ followed by 175 and $200 \mathrm{~kg} \mathrm{ha}^{-1}$ as against the seeding rate of $125 \mathrm{~kg} \mathrm{ha}^{-1}$. Actually, the maximum grain yield obtained from the use of higher seeding rate might be due to high density of plants and increased number of spikes per rows as a result number of grains and increased spike number in rows. Similar with the present finding, Haile, et al., (2013) who reported that the lowest seeding rate $\left(100 \mathrm{~kg} \mathrm{ha}^{\mathbf{- 1}}\right)$ resulted in a grain yield of $3851 \mathrm{~kg} \mathrm{ha}^{-1}$, which was significantly lower than the yields obtained at the other seeding rate $\left(150 \& 175 \mathrm{~kg} \mathrm{ha}^{-1}\right)$.

The same result also reported by Iqbal et al., (2010) who concluded that seeding rate of $150 \mathrm{~kg} \mathrm{ha}^{-1}$ produced significantly higher grain yield (4120 kg ha ${ }^{-1}$ ) followed by 175 and $200 \mathrm{~kg} \mathrm{ha}^{-1}$ seeding rates (3904 and $3785 \mathrm{~kg}$ $\mathrm{ha}^{-1}$ ). The seeding rate of $125 \mathrm{~kg} \mathrm{ha}^{-1}$ produced significantly lower grain yield (3.669 tones). Another research finding by Nazir et al., (2000) also showed that $150 \mathrm{~kg} \mathrm{ha}^{-1}$ seeding rate produced significantly the highest grain yield. According to the results of this study, increasing seeding rate would resulted in increasing grain yield due to using the maximum seed rate with the highest cost of production. However the economic analysis of this study showed the vice-versa results.

Based on the benefit to cost ratio analysis, the highest net benefit was obtained from treatment combination of the variety Hidassie/large seed size/ at seed rate of 300 seeds $\mathrm{m}^{-2}$, by using of the lowest plant density rate with low cost of production as shown on (Table 12). Likewise, Jemal Abdulkerim et al., (2015) also reported that varieties Shorima and Kekeba gave maximum grain yield at seeding rate of $150 \mathrm{~kg} / \mathrm{ha}$ and, variety Digalu produced highest yield at seeding rate of $175 \mathrm{~kg} \mathrm{ha}^{-1}$ as compared to $100,125, \& 200 \mathrm{~kg} \mathrm{ha}^{-1}$. Seleiman et al., (2010) also 
confirmed that increasing seeding rates up to 350 or 400 plants $\mathrm{m}^{-2}$ increased grain yield. Higher grain yield with higher seeding rates was also reported by Olsen et al., (2005) and Haile et al., (2010). The same result has also been proved by Sikander et al., (2003) who concluded that increasing seeding rate from 150 to $250 \mathrm{plants}^{-2}$ resulted in higher grain yield. However, in the economics context, top grain yield by itself does not reveals much about efficiency of production (CIMMYT 1988; Doberman et al., 2002) and hence, its production efficiency has been examined by partial budget analysis. It also derives out so evidently from research publications that technologies have been studied for potential yields but comparative economic analysis has not been part of it.

3.10.5. Harvest index \%

The analysis of variance indicated that the interaction effect of the varieties seed size and plant density on harvest index had significant $(\mathrm{P}<0.001)$ variations as shown on (Table 7). The highest harvest index $(43.63 \%)$ was obtained from the variety Hidassie/large seed size/ at the seeding rate of 300 plants $\mathrm{m}^{-2}$ followed by the harvest index $(42.33 \%)$ was obtained from the variety Dendea/medium seed size/ at the seeding rate of 350 plants $\mathrm{m}^{2}$ and the

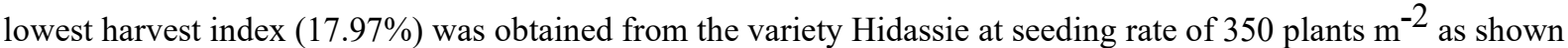
on (Table 10)

This shows that the bread wheat varieties seed size and plant density which implies that the main plot and sub plot factors influenced with each other in affecting harvest indexes. The capacity of a cultivar to change the dry matter into economic yield is showed by its harvest index. The higher the harvest index value, the greater the physiological potential of the crop for converting dry matter to grain yield (Abiot M., 2017). The analysis of variance showed that harvest index was significantly $(\mathrm{p}<0.01)$ affected by plant density.

\subsection{Economic Evaluation of the Grain Yields}

The Economic evaluation results of the varieties and plants density have been shown a consistent profitable response on grain yield of bread wheat. The results of the partial budget analysis and the economic data used in the development of the partial budget are illustrated in (Table 10).

Table 9. Total Costs of Different Items and Inputs Used in Partial Budget Analysis

\begin{tabular}{|c|c|c|c|c|c|c|c|c|c|c|c|c|}
\hline \multirow{3}{*}{$\begin{array}{l}\text { Cost of Items and } \\
\text { Services (ETB/ha) }\end{array}$} & \multicolumn{12}{|c|}{ Varieties and Plant Population Levels $\mathrm{m}^{-2}$} \\
\hline & \multicolumn{4}{|c|}{ Shorima } & \multicolumn{4}{|c|}{ Dendea } & \multicolumn{4}{|c|}{ Hidassie } \\
\hline & 250 & 300 & 350 & 400 & 250 & 300 & 350 & 400 & 250 & 300 & 350 & 400 \\
\hline \multirow{2}{*}{ Seed Cost. } & \multirow{2}{*}{1373} & 164 & 199 & 219 & 158 & 192 & 222 & 256 & 188 & 216 & 253 & 289 \\
\hline & & 7 & 2 & 9 & 6 & 2 & 7 & 3 & 0 & 6 & 2 & 8 \\
\hline $\begin{array}{l}\text { Fertilizer Cost- } \\
\text { NPS }\end{array}$ & 609 & 609 & 609 & 609 & 609 & 609 & 609 & 609 & 609 & 609 & 609 & 609 \\
\hline $\begin{array}{l}\text { Fertilizer Cost- } \\
\text { Urea }\end{array}$ & 333 & 333 & 333 & 333 & 333 & 333 & 333 & 333 & 333 & 333 & 333 & 333 \\
\hline Chemical Cost & 473 & 473 & 473 & 473 & 473 & 473 & 473 & 473 & 473 & 473 & 473 & 473 \\
\hline Wage for Planting & 568 & 568 & 568 & 568 & 568 & 568 & 568 & 568 & 568 & 568 & 568 & 568 \\
\hline $\begin{array}{l}\text { Wage for } 1^{\text {st }} \\
\text { Weeding }\end{array}$ & 530 & 530 & 530 & 530 & 530 & 530 & 530 & 530 & 530 & 530 & 530 & 530 \\
\hline $\begin{array}{l}\text { Wage for } 2^{\text {nd }} \\
\text { Weeding }\end{array}$ & 416 & 416 & 416 & 416 & 416 & 416 & 416 & 416 & 416 & 416 & 416 & 416 \\
\hline Wage & 108 & 108 & 108 & 108 & 108 & 108 & 108 & 108 & 108 & 108 & 108 & 108 \\
\hline Harvesting & 1080 & 0 & 0 & 0 & 0 & 0 & 0 & 0 & 0 & 0 & 0 & 0 \\
\hline Total Costs that & & 565 & 600 & 620 & 559 & 593 & 623 & 657 & 588 & 617 & 654 & 690 \\
\hline Varied & 5382 & 6 & 1 & 8 & 5 & 1 & 6 & 2 & 9 & 5 & 1 & 7 \\
\hline
\end{tabular}

3.11.1. Costs that Vary and the Inputs Price Data Collected

Data necessary for economic analysis was collected from the experiment field and from the nearest wheat producing farmers. All variable costs including land preparation, planting, weed control, and harvesting costs are estimated based on the actual field prices at the time of planting, and at vegetative growth stages as well as immediately after harvest; and assigned over the varieties and plant density levels. The variables buying costs and selling prices used for economic analysis is the 2018 and 2019 marketing costs and local market prices respectively, due to the better management conditions. The costs of NPS and N fertilizer were estimated based on the cost of NPS and Urea, respectively.

Ascendancy analysis, as recommended by CIMMYT (1988), was applied to screen treatments with higher 
variable costs, but lower net benefits; and dominated treatments eliminated from further considerations in Marginal analysis. The minimum acceptable rate of return was taken as $100 \%$; and treatments with lower minimum rates of return were also removed from further analysis. The above assigned seed prices are calculated with normal seed price of ETB 2288.00 per $150 \mathrm{~kg}$ ( 400 plants $\mathrm{m}^{-2}$ ) for one hectare, but it may become vary from this according to the varieties seed size. The total cost that vary (TVC) for lesser plant density levels was lower than the greater plant

density levels. On the other hand, lowest net benefit (NBV) was scored from Hidassie variety due to the highest seed rate of 400 plants $\mathrm{m}^{-2}$ which benefited ETB $32288.00 \mathrm{ha}^{-1}$. Relevant data to conduct preliminary assessment of economic analysis, yield levels were collected using data collecting formats that were developed to this effect. These were mainly the costs of inputs, wages, fertilizers, chemicals and the prices of outputs.

3.11.2. Partial Budget Analysis of Bread Wheat Yields

In order to organize the experimental data and information about the costs and benefits of various alternative treatments, a partial budget analysis was done to determine the economic impact of various alternative treatments as compared to the farmers' practice for bread wheat production at the study area. Local market (LM) price was used to calculate the product value. The cost of labour for weeding was taken at 35.00 ETB per day. Considering the costs that varied (cost of seed, fertilizers, chemicals and labour wage for planting, weeding and harvesting), the farmers' practice had a lower cost than the experimental method. In the partial budgeting analysis result of the present study, the costs for the different plant density levels varied according to their rates requirements being other costs were constant for each treatment.

In order to recommend the present results for the study area, it is necessary to estimate the minimum rate of return acceptable to farmers or producers in the recommendation domain. Based on partial budget analysis, the highest net benefit (49842 $\mathrm{ETB} \mathrm{ha}^{-1}$ ) was obtained from treatment combination of variety Hidassie/large seed size/ with a seed rate of 300 plants $\mathrm{m}^{-1}$, followed by net benefit (47411.00 ETB ha-1) was obtained from the treatment combination of variety Hidassie/large seed size/ with a seed rate of 250 plants $\mathrm{m}^{-2}$, while the lowest net benefit (32288.00 ETB/ha ${ }^{\mathbf{- 1}}$ ) was also obtained from the combination of variety Hidassie/large seed size/ with a seed rate of 400 plants $\mathrm{m}^{-2}$ only in one growing season as shown on (Table 10).

3.11.3. Benefit to Cost Ratio Analysis (BCR)

The benefit-cost ratio analysis was used in the cost-benefit analysis in order to summarize the overall relationship between the relative costs and benefits of the proposed research project in which the BCR was expressed in monetary terms. The alternatives are not simply ranked but can be quantitatively assessed one against the other. The highest benefit cost ratio of (8.07) with low marginal cost and more profitable MRR (8.50) was obtained from the variety Hidassie/large seed size/ at the use of 300 seeds $\mathrm{m}^{-2}$ seeding rate followed by (8.05) benefit cost ratio with the advantageous MRR (9.55) was recorded from the variety Hidassie/large seed size/ at seeding rate of 250 plants $\mathrm{m}^{-2}$ respectively (Table 12 and 10). Therefore, the most economical seed rates for small scale farmers of

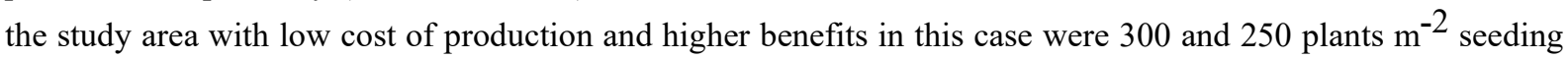
rates of variety Hidassie/large seed size/ respectively.

Table 10. Partial Budgeting Analysis of Bread Wheat Grain Yields.

\begin{tabular}{|c|c|c|c|c|c|c|c|c|}
\hline atment No & Variety & Plant Der & $\begin{array}{l}\text { Average } \\
\text { Grain } \\
\text { Yield } \\
\left(\text { Ton ha }^{-1}\right)\end{array}$ & $\begin{array}{c}\text { Adjusted } \\
\text { Grain Yield } \\
\left(\text { Ton } \mathrm{ha}^{-1}\right)\end{array}$ & $\begin{array}{c}\text { Total } \\
\text { Cost } \\
\text { that Vary } \\
\left(\mathrm{ETB} \mathrm{ha}^{-1}\right)\end{array}$ & $\begin{array}{c}\text { Gross Farm } \\
\text { Benefit } \\
\left(\text { ETB ha }^{-1}\right)\end{array}$ & $\begin{array}{l}\quad \text { Net } \\
\text { Benefit } \\
\text { Value } \\
\left(\mathrm{ETB} \mathrm{ha}^{-1}\right)\end{array}$ & $\begin{array}{c}\text { Benefit to } \\
\text { Cost } \\
\text { Ratio } \\
\text { (ETB) }\end{array}$ \\
\hline 1 & Shorima & 2500000 & 3.930 & 3.537 & 5382.00 & $45,981.00$ & 40599.00 & 7.54 \\
\hline 2 & Shorima & 3000000 Plants & 4.346 & 3.911 & 5656.00 & $50,843.00$ & 45187.00 & 7.99 \\
\hline 3 & Shorima & 3500000 Plants & 4.322 & 3.890 & 6001.00 & $51,740.00$ & 45739.00 & 7.62 \\
\hline 4 & Shorima & 4000000 Plants & 4.059 & 3.653 & 6178.00 & $47,489.00$ & 41311.00 & 6.69 \\
\hline 5 & Dendea & 2500000 Plants & 4.134 & 3.721 & 5595.00 & 73.00 & 42778.00 & 7.65 \\
\hline 6 & Dendea & 3000000 & 4.045 & & 31.00 & .00 & 41402.00 & 6.98 \\
\hline 7 & Dendea & 3500000 & 4.485 & 6 & 6236.00 & 3.00 & 46232.00 & 7.41 \\
\hline 8 & Dendea & 4000000 Plants & 4.865 & 4.379 & 6572.00 & $56,927.00$ & 50355.00 & 7.66 \\
\hline 9 & Hidassie & 2500000 Plants & 4.556 & 4.100 & 5889.00 & $53,300.00$ & 47411.00 & 8.05 \\
\hline 10 & Hidassie & 3000000 Plants & 4.788 & 4.309 & 6175.00 & $56,017.00$ & 49842.00 & 8.07 \\
\hline 11 & Hidassie & 3500000 Plants & 3.643 & 3.279 & 6541.00 & $42,627.00$ & 36086.00 & 5.52 \\
\hline 12 & Hidassie & 4000000 Plants & 3.350 & 3.015 & 6907.00 & $39,195.00$ & 32288.00 & 4.67 \\
\hline
\end{tabular}

Note: Cost of seed 15.25 ETB/kg; Labor Cost ETB 35/day; Field Sales price ETB 13.00/kg 
3.11.4. Adjusted Grain Yield Analysis of Bread Wheat

The adjusted yield is the average yield adjusted downward by a certain percentage of downward by $10 \%$ diminution to reflect the difference between the experimental yield and the yield farmers could expect from the treatment. Experimental yields, even from on-farm experiments under representative conditions, are often higher than the grain yields that farmers could expect using the same treatments (CIMMYT, 1988).

Table 11. Adjusted Grain Yield of Bread Wheat Varieties and Plants Density Experiment

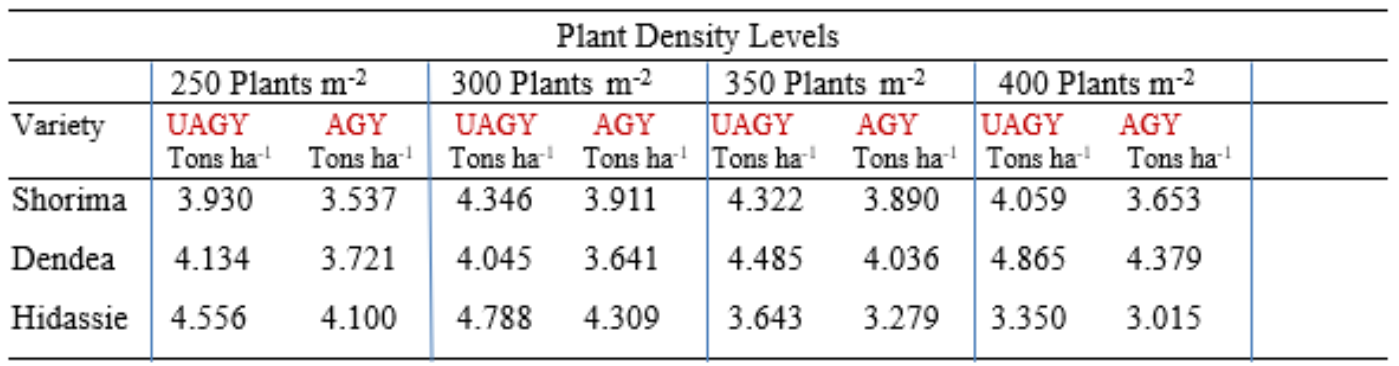

Note: - UAGY = unadjusted grain yield; AGY = adjusted grain yield

There are several reasons for yield adjustment insistences and just to emphasize some key points:

\section{- $\quad$ Field Management}

Researchers can often be more precise and sometimes more timely than farmers in operations such as plant spacing, fertilizer application, or weed control.

\section{- $\quad$ Plot Size}

Yields estimated from small plots often overstate the yield of an entire field because of errors in the measurement of the harvested area and because the small plots tend to be more uniform than the farmers large fields.

- Harvest Date. Researchers often harvest a crop at physiological maturity, whereas farmers may not harvest at the optimum time. Thus even when the yields of both researchers and farmers are adjusted to constant moisture content, the researchers' yield may be higher, because of fewer losses to insects, birds, rodents, ear rots, or shattering.

- Form of Harvest. In some cases farmers' harvest methods may lead to heavier losses than result from researchers' harvest methods. This might occur, for example, if farmers harvest their fields by machine and researchers carry out a more careful manual harvest. Unless some adjustment is made for these factors, the experimental yields will overestimate the returns that farmers are likely to get from a particular treatment.

One way to estimate the adjustment required is to compare yields obtained in the experimental treatment which represents farmers' practice with yields from carefully sampled check plots in the farmers' fields. Where this is not possible, it is necessary to review each of the four factors discussed earlier and assign a percentage adjustment.

3.11.5. Ascendancy Analysis of Bread Wheat Grain Yield

Ascendancy analysis procedure was carried to select potentially profitable treatments from the range that was tested. It was done first by listing the treatments in order of increasing costs that vary as shown on (Table 12). Any treatment that had net benefits that are less than or equal to those of a treatment with lower costs that vary is dominated.

Then the subjugated treatments were rejected from further economic analysis. It led to the selection of treatments, Hidassie/large seed size/ at seed rate of 250 and 300 seeds $\mathrm{m}^{-2}$, which ranked in equal order of the $\mathrm{BCR}$ respectively. The marginal rate of return for non-dominated treatments is stated in (Table 10). MRR among treatments of the variety Hidassie at seed rate of 300 seeds $\mathrm{m}^{-2}$ were lower than that of the treatments in the variety Hidassie at seed rate of 250 seeds $\mathrm{m}^{-2}$. It was finally to in that order would give positive MRR of 8.50 and 9.55 respectively. 
Table 12. Ascendancy Analysis of Bread Wheat Grain Yields

\begin{tabular}{|c|c|c|c|}
\hline \multicolumn{2}{|c|}{ Treatment No.Variety/Seed Size } & \multicolumn{2}{|c|}{ NBV (ETB ${ }^{-1}$ ha)Ascendancy } \\
\hline 1 & Shorima/Small Sized Seeds 250 plants $\mathrm{m}^{-25,382.00}$ & $40,599.00$ & \\
\hline 5 & Dendea/Medium Sized Seeds 250 plants $\mathrm{m}^{-25,595.00}$ & $42,778.00$ & \\
\hline 2 & Shorima/Small Sized Seeds 300 plants $\mathrm{m}^{-25,656.00}$ & $45,187.00$ & \\
\hline 9 & Hidassie/Large Sized Seeds 250 plants $\mathrm{m}^{-25,889.00}$ & $47,411.00$ & \\
\hline 6 & Dendea/Medium Sized Seeds 300 plants $\mathrm{m}^{-25,931.00}$ & $41,402.00$ & Subjugated \\
\hline 3 & Shorima/Small Sized Seeds 350 plants $\mathrm{m}^{-26,001.00}$ & $45,739.00$ & Subjugated \\
\hline 10 & Hidassie/Large Sized Seeds 300 plants $\mathrm{m}^{-26,175.00}$ & $49,842.00$ & \\
\hline 4 & Shorima/Small Sized Seeds 400 plants $\mathrm{m}^{-26,178.00}$ & $41,311.00$ & Subjugated \\
\hline 7 & Dendea/Medium Sized Seeds 350 plants $\mathrm{m}^{-26,236.00}$ & $46,232.00$ & Subjugated \\
\hline 11 & Hidassie/Large Sized Seeds 350 plants $\mathrm{m}^{-26,541.00}$ & 36.086 .00 & Subjugated \\
\hline 8 & Dendea/Medium Sized Seeds 400 plants $\mathrm{m}^{-26,572.00}$ & $50,355.00$ & \\
\hline 12 & Hidassie/Large Sized Seeds 400 plants m ${ }^{-26,907.00}$ & $32,288.00$ & Subjugated \\
\hline
\end{tabular}

Note: $\mathrm{PDL}=$ plant density level; $\mathrm{TVC}=$ total variable cost; $\mathrm{NBV}=$ net benefit value.

The changes to the variety Shorima at plant density levels of 250 seed $\mathrm{m}^{-2}$ is rejected for this reason to remain

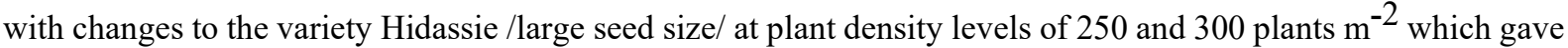
more than $100 \%$ MRR as promising new practices for farmers under the prevailing price structure (Table 13). According CIMMYT (1988), the minimum acceptable marginal rate of return (MRR) should be $100 \%$.

Table 13. Marginal Analysis Effects of Bread Wheat Grain Yield

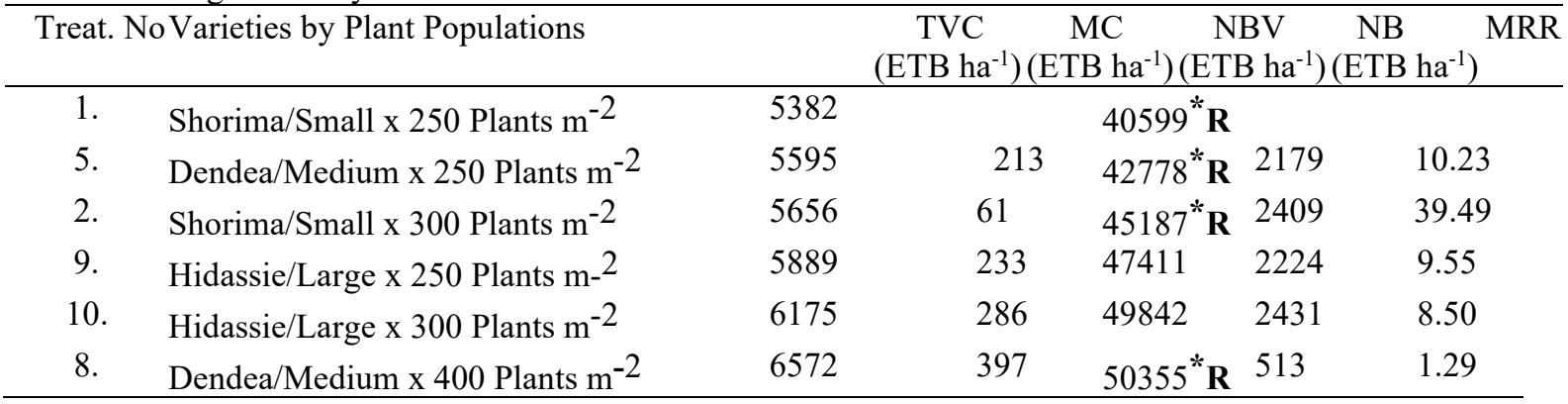

Note: ${ }^{*} \mathbf{R}=$ removed; $\mathrm{PPL}=$ plant density level; $\mathrm{TVC}=$ total variable cost; $\mathrm{NBV}=$ net benefit value;

$\mathrm{MNB}=$ marginal net benefit; $\mathrm{MRR}=$ marginal rate of return .

As stated by CIMMYT (1988), recommendation is not necessarily based on the highest yield and even not based on the highest MRR. Recommendation is just based on the highest net benefit cost ratio and thus, the most economically superior variety and seed rate for farmers of the study area with low cost of production and the highest net benefits were identified to be the variety Hidassie /large seed size/ at seeding rate of $300 \mathrm{plants} \mathrm{m}^{-2}$ $\left(142.00 \mathrm{~kg} \mathrm{ha}^{-2}\right)$. The seeding rate of 250 plants $\mathrm{m}^{-2}\left(118 \mathrm{~kg} \mathrm{ha}^{-2}\right)$ of this variety was also profitable with the highest net benefit and recommended as $2^{\text {nd }}$ option. Consistent with the partial budgeting analysis results, it can be determined that the most profitable treatment was the variety Hidassie /large seed size/ which gave the highest benefit cost ratio of (8.07) and MRR (8.50) at seed rate of 300 plants $\mathrm{m}^{-2}$ whereas, alternatively the MRR of (9.55) and benefit cost ratio (8.05) were attained also from the variety Hidassie /large seed size/ at seeding rate of 250 plants $\mathrm{m}^{-2}$ as shown on (Tables $8 \& 10$ ).

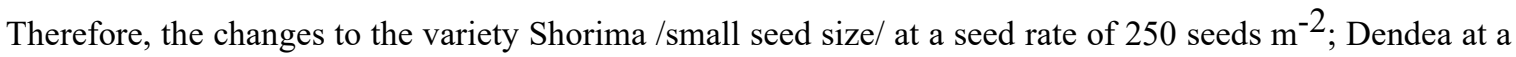
seed rate of 250 seeds $\mathrm{m}^{-2}$, Shorima /small seed size/ at a seed rate of 300 plants $\mathrm{m}^{-2}$ and Dendea at a seed rate of 400 plants $\mathrm{m}^{-2}$ are removed for their low benefit cost ratio and to remain with the changes to variety Hidassie/large seed size/ at seed rate of 300 and 250 plants $\mathrm{m}^{-2}$. The yield of treatment 8 is higher than that of treatment 10 as shown on (Table 8), but the dominance analysis shows that the value of the increase in yield is not enough to compensate the increase in costs. Farmers would be better off using the lower seed rate with lower costs. 


\section{CONCLUSION}

One of the great challenges encountering Ethiopia at present is the production of sufficient food to feed the quickly increasing population growth. Getting more agricultural land-dwelling into farming is not possible in the closely inhabited regions. Improved agricultural productivity requires higher yields per unit land area, which increases the demand of improving the production and productivity of bread wheat. Concerning varietal variations, previously studies revealed that selecting varieties which are related to the specified population and use by farmers may be a feasible option for improving bread wheat yields. Based on the result of the economic analysis, among four plant density levels the use of 300 and 250 seeds $\mathrm{m}^{-2}$ for the variety Hidassie /large seed size/ is superior in most of bread wheat agronomic traits. The wheat seed sizes and plant density levels interaction showed that most economical and profitable grain yield of 4100 and $4339 \mathrm{~kg} \mathrm{ha}^{-1}$ was produced at seed rate of 250 and 300 plants $\mathrm{m}^{-2}$ for the variety Hidassie /large seed size/ respectively. According to the partial budgeting analysis, a visible advantageous and more profitable dominance with low cost of the variety Hidassie/large seed size/ at plant density of 300 plants $\mathrm{m}^{-2}\left(142 \mathrm{~kg} \mathrm{ha}^{-1}\right)$ and 250 plants $\mathrm{m}^{-2}\left(118 \mathrm{~kg} \mathrm{ha}^{-1}\right)$ was found to be over the other varieties.

This shows that the variety Hidassie is genetically better in grain yield than varieties Dendea and Shorima. As a whole, significant variations in grain yield and most of agronomic parameters of bread wheat were observed due to variety seed size and plant density levels. The current study suggested that sowing bread wheat with large sized seeds such as the variety Hidassie was peculiarly beneficial with most encouraging agronomic performance. The economic analysis of the experiment was brought to select the best combination of the variety Hidassie/large seed size/ at a plant density rate of 300 plants $\mathrm{m}^{-2}\left(142.00 \mathrm{~kg} \mathrm{ha}^{-1}\right)$ gave the greatest grain yield $\left(4339 \mathrm{~kg} \mathrm{ha}^{-1}\right)$ with low cost of production and higher net benefits and can be recommended tentatively as a $1^{\text {st }}$ option for the study area.

Alternatively, the variety Hidassie/large seed size/ at a plant density level of 250 plants $\mathrm{m}^{-2}\left(118 \mathrm{~kg} \mathrm{ha}^{-1}\right)$ gave better yield (4100 $\mathrm{kg} \mathrm{ha}^{-1}$ ) with a slightly additional cost rather than the primarily recommended seed rate and can be recommended as a $2^{\text {nd }}$ option for the small scale farmers of the study area. However, since this study was only at one location for single cropping season it is advisable to conduct further research and it is better to repeat the experiment across locations, soil type, and over seasons to make reliable and acceptable recommendations for a wide-ranging of agro- ecological zones.

\section{ACKNOWLEDGMENT}

This study was self-sponsored project and does not financially sported by any internal or external funding organizations. The authors would like to acknowledge colleagues who work at Seed Quality Research Laboratory and Soil Analysis Laboratory of Kulumsa Agricultural Research Center for their timely analysis of the seed samples and soil samples respectively. Our sincere gratitude is also due to the wonderful cooperation of the researchers at Kulumsa Agricultural Research Center for their technical and analytical advices while conducting this study.

\section{REFERENCES}

Abayneh E., Demeke T., Gebeyehu B., \& Kebede A. (2003).Technical Paper No 76, Soil of Kulumsa Research Center, The Federal Republic of Ethiopia, Ethiopian Agricultural Research Organization (EARO), National Soil Research Center (NSRC), Soil Survey and Land Evaluation Section, Addis Ababa. pp. (iii):1-14

Abiot M., (2017). Effects of Seeding Rate and Row Spacing on Yield and Yield Components of Bread Wheat (Triticum aestivum L.) in Gozamin District, East Gojam Zone, Ethiopia. Journal of Biology, Agriculture and Healthcare www.iiste.org ISSN 2224-3208 (Paper) ISSN 2225-093X (Online) Vol.7, No.4, 2017.

Akbar Muhammad, Muhammad Tariq, Tayyab Jamil, Muhammad Arshad. (2001). Evaluation of exotic wheat germplasm for seed yield \& its components under rain fed conditions. Sarhad J. Agric., 17(4): 511-513.

Ali, M., L.Ali, M.Sattar and M.A.Ali. (2010). Improvement in wheat (Triticum aestivum L.) Yield by manipulating seed rate and row spacing in vehari zone. Adaptive Research Farm, Vehari. Journal of Animal and Plant sciences, 20(4) pp. 225-230.

Anbessie Debebe A., Abebe M., Dechassa H. (2020). Effect of Plant Population on Growth, Yields and Quality of Bread Wheat (Triticum Aestivum L.) Varieties at Kulumsa in Arsi Zone, South-Eastern Ethiopia, International Journal of Research Studies in Agricultural Sciences (IJRSAS), 2020; 6(2), pp.32-53, http://dx.doi.org/ 10.20431/2454- 6224.0602005

Atwell, W.S., Finnie A., (2001). Wheat Flour - 2 ${ }^{\text {nd }}$ Edition-ISBN: 9781891127908, 9780128123669, Eagan Press, Department of Food Science and Nutrition, University of Minnesota, St. Paul, Minnesota, USA.

A., Zareian, L. Yari, F. Hasani and G.H. Ranjbar (2012). Field Performance of Three Wheat (Triticum aestivum L.) Cultivars in Various Seed Sizes. World Applied Sciences Journal 16 (2): 202-206, 2012 ISSN 1818- 4952 
Baloch, M. S., I.T.H. Shah, M. A. Nadim, M. I. Khan and A. A. Khakwani. (2010). Effect of Seeding Density and Planting Time on Growth and Yield Attributes of Wheat. J.Anim. Pl.Sci. 20(4):239-240

Bavec, M., F. Bavec, B. Varga and V. Kovacevic, (2002). Relationships among yield, it's quality and yield components, in winter wheat (Triticum aestivum L.) cultivars affected by seeding rates. Bodenkultur, 53: $143-151$.

Birhan A. I., (2006). Response of Haricot Bean (Phaseolus Vulgaris L.) To Nitrogen, Phosphorus and Inoculation of Rhizobium Phaseoli at Melkassa

Bordes J., F. Balfourier. (2008). Agronomic Charecterstics, grain quqlity and flour rheology of 372 bread wheats in worldwide core collection. Journal of ceral Science, Volume 48, Issue 3, November 2008. pp. 569-579

Bouyoucus, C.J. (1951). A recaliberation of hydrometer method for making mechanical analysis of soils. Agronomy Journal. 43:434-438.

Braun H-J., G. Atlin and T. Payne (2010). Multi-location testing as a tool to identify plant response to global climate change. In: Climate change and crop production (ed. M.P. Reynolds). CABI International, pp 115138.

Center for New Crops \& Plant Products, Purdue University. (2003). Triticumspecies.http://www.hort.purdue.edu/ newcrop/nexus/ Triticum_spp_nex.html

Chaudhary M.A., A. Ali, M. A. Siddique and R.Sohail. (2000). Growth and yield response of wheat to different seed rates and wild oat (Avenafatua) competition durations. Pakistan J. Agri. Sci. 37 (3-4): 152- 154.

Cheruth, A.J.,Gopi, R., Sankar, B., Gomathinayagam, M., \& Panneerselvam, R. (2008). Differential responses in water use efficiency in two varieties of Catharanthus roseus under drought stress. Comptes rendus, Biologies, $331(1), 42-47$.

CIMMYT, (1988). An Economics Training Manual. Completely Revised edition, Mexico, DF. ISBN968-6127$18-6$

CSA, (2018). Agricultural sample survey: Report on area and production of major crops, Volume 1, Report on Area and production of Major Crops, Private Peasant Holdings, Meher Season, Statistical Bulletin 589, Addis Ababa, Ethiopia.

Dawit Habte., (2017), Technical Manual, Volume 1, Planning \& Management of Field Experiments in Agricultural Research, Ethiopian Institute of Agricultural Research, Addis Ababa, Ethiopia. pp. 99-100.

Dobermann, A and K.G Cassman. (2002). Plant nutrient management for enhanced productivity in intensive grain production systems of the United States and Asia. Plant and Soil, 247:153-175.

EIAR, (2015). Technical Report of Soil \& Water Research Process, Kulumsa Agricultural Research Center (KARC), A report submitted for Eastern Africa Agricultural Productivity Improvement Project (EAAP) Ethiopian Institute of Agricultural Research, Addis Ababa, Ethiopia. pp. 3-4

Gafaar, N A. (2007). Response of some bread wheat varieties grown under different levels of planting density and nitrogen fertilizer. Minufiya Journal of Agriculture, 32: 165-183

Haile Deressa and Girma, F. (2010). Integrated Effect of Seeding Rate, Herbicide Dosage and Application Timing on Durum Wheat (Triticum Turgidum L. Var Durum) Yield, Yield Components and Wild Oat (Avena Fatua L.) Control in South Eastern Ethiopia. Oromia Agricultural Research Institute, Sinana Agricultural Research Center, P.O. Box 208, Bale-Robe, Ethiopia.

Hailu Gebre-Mariam. (1991). Wheat production and research in Ethiopia.pp.1-136. In: Hailu GebreMariam, Tanner,D.G.and Mengistu Huluka (eds). Wheat research in Ethiopia: IAR/CIMMYT, Addis Ababa, Ethiopia.

Hameed, E., S.A. Wajid, A.A. Shad, J. Bakht and T. Muhammad. (2003). Effect of different planting dates, seedrates and nitrogen levels on wheat. Asian Journal of Plant Science. 2 (6):464-474

Hameed, E., S. A. Wajid, A. A. Shad, J. Bakht and T. Muhammad. (2002). Effect of different planting dates, seed rates and nitrogen levels on wheat. Asian. J. Plant Sci. 2(6): 464-474.

Hussain, I., Muhammad Ayyaz Khan and Hayatullah Khan. (2010). Effect of seed rates on the agro- physiological traits of wheat. Department of Agronomy, Faculty of Agriculture, Gomal University, Dera Ismail KhanPakistan.

Ijaz, A.K., J. Bakht, S.A.,Wajid, N.M., Khan and I. Ullah. (2002). Effect of seed rate on the yield and yield components of wheat under irrigated conditions of Peshawar. Asian. J. Plant Science. 1:513-515.

Iqbal, J., K. Hayat, S. Hussain, A. Ali, M. Ahmad Alias and H. Ahmad Bakhsh. (2012). Effect of Seeding Rates and Nitrogen Levels on Yield and Yield Components of Wheat (Triticum aestivum L.). Pakistan Journal of Nutrition 11 (7): 531-536.

Jackson, M.C., (1975). Soil Chemical Analysis. Prentice Hall, Inc., Englewood Cliffs

Jan, A., I. Hamid and T.J. Muhammad, (2000). Yield and yield components of wheat as influenced by seed rates and sowing dates. Pak. J. Biol. Sci., 3: 323-325.

Jemal Abdulkerim, Tamado Tana and Firdissa Eticha. (2015), Response of Bread Wheat (Triticum aestivum L.) Varieties to Plant density levels at Kulumsa, South Eastern Ethiopia. Asian Journal of Plant Sciences 14 (2): 50-58, ISSN 1682-3974. 
Khan, M. A., J. Anwar, A. Sattar and M. A. Akhtar. (2001). Effect of seed rate on wheat yield under different sowing dates \& row spacing. J.Agric. Res.39 (3-4):223-229.

Khan, A. Z., H. Khan, R. Khan, Adel Ghoneim and A. Ebid. (2002). Effect of sowing date \& seed rates on yield \& yield components of wheat. Trendsin Applied Sci.Res., 2(6):529-534.

London J. R. (1991). Booker tropical soil manual: A Handbook for Soil Survey \& agricultural land evaluation in tropics \& sub tropics. Longman scientific \& technical publishing, New York.

M.R. \& H. Asadi, (2006). Agronomical \& economical assessment of planting methods and seeding rates in irrigated wheat (Triticum aestivum L.). Journal of Agronomy,5: 626-633.

MoANR, (2016). Plant Variety Release, protection and Quality Control Directorate, Crop Register, Issue No. 19, Addis Ababa, Ethiopia.

MoANR, (2010). Plant Variety Release, protection and Quality Control Directorate, Crop Variety Register, Addis Ababa, Ethiopia.

N. J. Jaleel, C. A., Manivannan, P., Sankar, B., Kishorekumar, A., Gopi, R., Somasundaram, R., \& Panneerselvam, R. (2007). Water deficit stress mitigation by calcium chloride in Catharanthus roseus; effects on oxidative stress, proline metabolism and indole alkaloid accumulation. Colloids Surf. B: Biointerfaces, 60, 110-116.

N. Majnoun Hosseini, R. H. Ellis and B. Yazdi-Samadi, (2001). Effects of Plant Density Density on Yield and Yield Components of Eight Isolines of cv. Clark (glycine max L.) J.Agric.Sci. Technology. Vol. 3: 131-139.

Nazir, M.S., A. Jabbar, Z. Waheed, A. Gaffar and M. Aslam, (2000). Response of lately sown wheat to seeding density and nitrogen management. Pak. J. Biol. Sci., 3: 998-1001.

Olsen, J., Kristensen L., Weiner, J \& Griepentrog, H. W. (2005). Increased density and spatial uniformity increase weed suppression by spring wheat (Triticum aestivum). Weed Research, 45:316-321.

Olsen, S.R., C.V. Cole, F.S. Watanabe and L.A. Dean. (1954). Estimation of available phosphorous in soils by extraction with sodium bicarbonate. pp. 1-9. USDA.

Otteson B.N., M. Mergoum and J.K.Ransom, (2007). Seedinf rate and nitrogen Management effects on spring wheat yield and compnents. Aron. J., 99: 1615-1621.

Otteson, B.N., M. Mergoum, and J.K. Ransom. (2008). Seeding rate and nitrogen management on milling and baking quality of hard red spring wheat genotypes. Crop Science 48:749-755.

Seleiman, M.F., Ibrahim, M.E., Abdel-Aal, S.M. and Zahran, G.A. (2010). Effect of seeding rates on productivity, technological and rheological characteristics of bread wheat (triticum aestivum L.). International Journal of Current Research. Vol4, pp. 075-08.

Shahzad M. A., Shahi S.T., Khan, M. M. (2007). Effect of sowing dates and seed seed treatment on yield and quality of wheat. Pakistan Journal of Agricultural Sciences, Department of Agronomy, Wasi-ud-Din SubCampus Depalpur University of Agriculture, Faisalabad Pakistan.

Shock, C.C., Feibert, E.B.G., and Saunders, L.D. (1998). Onion yield and quality affected by soil water potential as irrigation threshold. HortScience, 33, 1188-1191.

Sikander, K., I. Hussain K. Tanveer, M. Sohail, N.S. Kissana and S.G. Abbas. (2003). Effects of different planting methods on yield and yield components of wheat. Asian J. Plant Sci., vol. 2, pp. 811-813.

Tayyar, S., (2010). Variation in grain yield and quality of Romanian bread wheat varieties compared to local varieties in North-western Turkey. Roman. Biotechnol. Lett.15:5189-5196.

Tekalign Tadesse. (1991). Soil, plant, water, fertilizer, animal manure and compost analysis. Working document No. 13. ILCA, Addis Ababa.

Tunio, S.D., M.N. Korejo, A.D. Jarwar, and M.R. Waggan. (2006). Studies on indigenous and exotic weed competition in wheat. Pak. J. Agri. Biol. 5(4): 1-8.

USDA, (2017). United States Department of Agriculture, World Agricultural Production, Foreign Agricultural Service, Office of Global Analysis, International Production Assessment Division, Circular Series, WAP 0517, May 2017.

Van Reeuwijk, L.P. (1992). Procedures for soil analysis ( $3^{\text {rd }}$ ed.). International Soil Reference and Information center (ISRIC), Wageningen, The Netherlands.

Walkley, A. and C.A. Black. (1934). An examination of digestion method for determining soil organic matter and proposed modification of the chronic acid titration method. Soil Science Journal. 37:29-38.

Worku Awdie. (2008). Effects of nitrogen and seed rates on yield and yield components of bread wheat (triticumaestivum L.) in yelmana densa district, northwestern Ethiopia. M.Sc. Thesis. The School of Graduate

Zewdie Bishaw, Paul C. Struik. et al., (2014). Assessment of on-farm diversity of wheat varieties and landraces: evidence from farmer's field in Ethiopia. African Journal of Agricultural Research, 9 (38): 2948-2963. 